Volume 6

Number 1 Volume 6, No. 1, 1984

Article 2

1984

\title{
To Open Wider, or to Close Again: China's Foreign Investment Policies and Laws
}

An Chen

Follow this and additional works at: https:// digitalcommons.nyls.edu/

journal_of_international_and_comparative_law

Part of the Law Commons

\section{Recommended Citation}

Chen, An (1984) "To Open Wider, or to Close Again: China's Foreign Investment Policies and Laws," NYLS Journal of International and Comparative Law: Vol. 6 : No. 1 , Article 2.

Available at: https://digitalcommons.nyls.edu/journal_of_international_and_comparative_law/vol6/iss1/2

This Article is brought to you for free and open access by DigitalCommons@NYLS. It has been accepted for inclusion in NYLS Journal of International and Comparative Law by an authorized editor of DigitalCommons@NYLS. 


\section{NEW YORK LAW SCHOOL JOURNAL OF INTERNATIONAL AND COMPARATIVE LAW}

TO OPEN WIDER, OR TO CLOSE AGAIN: CHINA'S FOREIGN INVESTMENT POLICIES AND LAWS

\section{AN CHEN*}

Foreign investment in China is, at once, an issue of great age and great youth. Against the historical backdrop of Western exploitation during the second half of the nineteenth and first half of the twentieth centuries, and policies alternating between shutting out or accepting foreign investment, China's leaders have now determined that the "awakening Giant" can withstand and prosper with the help of foreign investment while relying on China's own efforts. ${ }^{1}$ But will China treat her business guests with traditional hospitality or so-called xenophobia after they have entered the door? This article examines China's developing legal framework for absorbing foreign investment and comments on the emerging legal threshold at China's door.

\section{The 1982 Constitution}

Any discussion of the foreign investment laws of the People's Republic of China (PRC) necessarily begins with the fundamental authorization for such investment, namely article 18 of the 1982 Constitu-

- Professor of Law, Associate Dean, School of Politics \& Law, Xiamen University; Consultant to Fujian Overseas Chinese Affairs Legal Service, People's Republic of China; Visiting Scholar at Harvard Law School 1981-84.

1. See H. Kapur, The Awakgning Giant: China's Ascension in World Politics (1981). 
tion. ${ }^{2}$ Under that article:

The People's Republic of China permits foreign enterprises, other foreign economic organizations or individual foreigners to invest in China and to enter into various forms of economic cooperation with Chinese enterprises or other economic organizations in accordance with the law of the People's Republic of China. All foreign enterprises and other foreign economic organizations in China, as well as joint ventures with Chinese and foreign investment located in China, shall abide by the law of the People's Republic of China. Their lawful rights and interests are protected by the law of the People's Republic of China. ${ }^{3}$

The 1982 Constitution is, for the purposes of foreign investors, a landmark document. None of the three previous Chinese Constitutions (1954, 1975 and 1978) made an allowance for foreign investment. ${ }^{4}$ It was, in fact, officially disapproved. As we see from the marked economic change embodied in article 18 of the 1982 Constitution, however, foreign investment is not only approved of and "protected by the law of the People's Republic of China," it is officially encouraged. With this hopeful documentary prelude, let us examine China's developing framework for opening to the outside world and absorbing foreign investment.

\section{Current Policies}

Two comprehensive documents exemplify Beijing's present commitment to attracting foreign investment. One is a concise handbook, compiled by the Chinese Ministry of Foreign Economic Relations and Trade (FERT) prior to May 1982, entitled Questions and Answers Concerning Foreign Investment in China (FERT Handbook), ${ }^{6}$ which

2. Xianfa (Constitution) art. 18 (PRC), Renmin Ribao (People's Daily), Dec. 5, 1982, at 1 , reprinted in Beising Rev. No. 52, at 10 (adopted by the Fifth Session of the Fifth National People's Congress on Dec. 4, 1982).

3. Id.

4. Xinnpa (Constitution) of 1954 , reprinted in 3 Constitutions of Nations 261 (3d ed. 1965) (adopted by the First Session of the First National People's Congress on Sept. 20, 1954); Xianfa (Constitution) of 1975, reprinted in Wang. Selected Legal Documents of the People's Republic of China (1976) (adopted by the First Session of the Fourth National People's Congress on Jan. 17, 1975); XIANFA (Constitution) of 1978, reprinted in BeiJing Rev. No. 11, at 5 (adopted by the Fifth National People's Congress on Mar. 5, 1978, amended July 1, 1979, promulgated on Jan. 1, 1980).

5. See Answers, infra note 6 , at 1 .

6. See Questions and Answers Concerning Foreign Investment in China, China Economic News (Hong Kong), Supp. No. 3, May 12, 1982 [hereinafter cited as Answers]. 
addresses forty-four concrete problems. The second document is a substantial speech made by Wei Yuming, Vice-Minister of FERT, entitled "On China's Policy for Absorbing Direct Investment from Foreign Countries." The speech was delivered at the June 7, 1982 opening ceremony of a large-scale China investment promotion meeting in Guangzhou, which was jointly sponsored by the Chinese Government and the United Nations Industrial Development Organization.

The Ministry's handbook explained a series of important policies on foreign investment in China that foreign businessmen were eager to understand. Based on the laws, decrees, rules and regulations that had been promulgated or would be enacted, the document covered a wide range of subjects. These subjects included priority requirements for establishing joint ventures; safety guarantees and approval procedures; rights of the boards of directors of joint ventures and decisionmaking power of enterprises; the purchase of raw materials, fuel and power; the sale of products; tax treatment for joint ventures; fees for the use of sites; labor and wages; the services rendered by the Bank of China to joint ventures; the financing and accounting systems of joint ventures and the settlement of disputes between the participants in a joint venture. This document is considered essential for foreign investors in China.

The latter document, the speech of Vice-Minister Wei, however, is equally as, if not more important than the Ministry's handbook. Mr. Wei's statements were not just the individual opinion of a high-ranking official, nor merely the common view of the Ministry of FERT, but a general reflection of the views of the collective leadership in China. Moreover, the speech was delivered at a large-scale meeting of international character; it has been considered the equivalent of an official government policy statement. ${ }^{\mathrm{B}}$

Since 1979 China's legislature has made considerable progress in developing a framework for the absorption of direct foreign investment. ${ }^{9}$ Following promulgation of the Law of the PRC on Chinese-For-

7. Wei Yuming, On China's Policy for Absorbing Direct Investment From Foreign Countries, Wen Hui Bao (Hong Kong), June 8, 1982 [hereinafter cited as Wei's Speech].

8. In the same speech, Wei said: "Now please allow one to take this opportunity to make an introduction and some explanations on our government's policy for absorbing direct foreign investment." Id.

9. China has adopted a variety of forms to attract foreign capital. At present there are roughly three ways of utilizing foreign investment in China: (1) the absorption of direct investment from foreign countries, including joint ventures, cooperation enterprises, joint exploration and development, and compensation trade; (2) endeavoring to obtain medium and long-term loans at low to medium interest rates from various exploration and development foundations and from foreign governments and international financial organizations and (3) ordinary commercial loans. For the present and in the near 
eign Joint Ventures, the Government has passed a succession of supplemental regulations. ${ }^{10}$ From these laws and regulations four overriding policies have emerged.

\section{A. Coordination with China's Economic Aims}

The acceptance of direct investment from foreign countries is conditional on the investment's ability to assist in the readjustment of China's national economy, the modernization program and the improvement of China's quality of life. These three interrelated aims are paramount in China's domestic economic activities. It is no surprise that foreign investment is required to further these goals.

China's push for modernization has centered on certain industries. These industries include: (1) energy; (2) textiles and light industry; (3) food; (4) pharmaceuticals; (5) telecommunications and electronics; (6) building materials, iron, steel and chemicals; (7) agriculture, animal husbandry and breeding and (8) tourism. This partiality is illustrated by the fact that of the forty joint ventures approved in 1982, there were thirteen light industrial projects, two woolen textile industrial projects, nine machinery and electronics industrial projects, three foodstuff industrial projects, one pharmaceutical industrial project, one agricultural project, two breeding projects and eight tourist projects. ${ }^{11}$

Several other characteristics or factors of foreign investment may be necessary for the investment to be looked upon favorably. The investment should: (1) be conducive to the adoption of advanced technology and scientific management; (2) bring about a quick profit return and help to carry out as much technological transformation of existing enterprises as possible; (3) increase exports and foreign exchange earnings and (4) help train technical and management personnel.

China gives great preference to foreign investment that will renovate or transform an existing or defunct industrial operation. The country currently has about 400,000 enterprises of varying sizes. More than half of all successful joint ventures in China have been formed on the basis of former enterprises, ${ }^{12}$ and it is to be hoped that this trend

future, absorbing direct investment should be the most important form.

10. See e.g., Answers, supra note 6, at 3, for a list of regulations and promulgations implemented to effectuate the Law of the PRC on Chinese-Foreign Joint Ventures. See infra note 13.

11. See Answers, supra note 6, at 2.

12. In a recent interview with a Hong Kong correspondent, Mr. Cao Jiarui, the Deputy Director of the Ministry of FERT's technical import and export bureau, stated that the Chinese Government is now giving priority attention to the technical transformation of the country's existing enterprises, and that the nation's economic growth will depend upon this transformation to a large extent. Chinese industrial establishments are inter- 
will continue.

\section{B. Just Rights and Legal Profits}

In absorbing foreign investment, it is imperative to implement the principles of equality and mutual benefit, and to ensure the just rights and legal profits of China as well as the foreign investors. In handling and developing its economic and trade relationships with foreign countries, China has consistently upheld these principles; in absorbing direct foreign investment, it has done the same. China has followed this policy for the last five years. The agreements, contracts and regulations signed with foreign investors have been reached only after full consultation on the basis of equality. No article has been agreed to which harms Chinese rights and interests or those of the foreign investors. The rights and interests of both sides have been taken into consideration so that foreign investors have a good prospect for gain.

Similarly, a joint venture or cooperation enterprise is managed jointly by the parties concerned and is under the leadership of its board of directors. Business management is wholly supervised by the board of directors and a managerial organ under the board of directors. All major problems are discussed and a solution is developed by the board of directors formed jointly by both sides. The just rights and legal profits of the joint venture are protected by the relevant laws of the PRC. All parties joining in the venture are equal under Chinese law, and no one is discriminated against. In the past five years, China has implemented the principle of equality and mutual benefits and the foreign partners have showed their sincerity through cooperation.

In organizing joint ventures and cooperation enterprises, some foreign countries have questioned whether the Chinese Government will confiscate or requisition the investment or properties of the foreign partners. This concern is unnecessary. In the last thirty years, China has kept its promises in handling foreign relations, being both true in word and resolute in deed. People can have confidence, therefore, that China will not confiscate foreign investors' capital, provided that these investors do not violate the laws of the PRC, and that the ventures they undertake do not harm China's public interest and public order.

ested in importing advanced and small projects which call for a small investment but produce swift results. One of the most important changes in technological importation, therefore, has been the great increase in the number of items serving the needs of technical transformation in existing enterprises. Its proportion under state planning accounted for $0.7 \%$ of the total value of technological and equipment imports in 1979. It rose to $36.7 \%$ in 1981. See Tech Import Chief on Changes in China's Technology Import Policy, China Economic News (Hong Kong), No. 44, Nov. 15, 1982, at 4. 
Even if China requisitioned foreign invested assets due to large-scale war, natural disasters or events beyond its control, the Government would compensate foreign investors for the requisition according to legal procedures and the principles of fairness and reasonableness. ${ }^{13}$

\section{Full Decisionmaking Power}

It must be ensured that joint ventures and cooperation enterprises using Chinese and foreign investment enjoy flexible decisionmaking power. These enterprises using Chinese and foreign investment are a special form of economic organization in the host country. Because they are different from the state-run and collective enterprises, they should be allowed to adopt more flexible measures in management according to their characteristics and needs. It must be ensured, therefore, that the joint venture enterprise enjoys full decisionmaking power in handling affairs concerning personnel, finance, material allocation, supply, production and marketing. Provided that the enterprise subjects itself to the guidance of the state plan and abides by the applicable Chinese laws, regulations and stipulations, the joint venture and cooperation enterprise, using both Chinese and foreign investment, enjoys decisionmaking power in the following areas:

(1) To make decisions on its development program, and plans concerning production, management and labor wages. (These programs and plans should be reported to administrative departments and local labor departments for the record.)

(2) To buy the necessary raw materials, fuel and equipment including components, spare parts and accessories on domestic and international markets, and sell products on these markets according to the provisions of the contracts signed.

(3) To sign economic contracts with domestic and foreign companies and enterprises, and realize its own plans by implementing economic contracts.

(4) To raise renminbi (Chinese currency) and foreign exchange from domestic and overseas financial institutions for production and management. They can open renminbi or foreign exchange accounts with the Bank of China or with other banks, with the approval of the Bank of China, for free deposit and withdrawal of funds raised and used by themselves.

(5) To establish financial and other management systems for the

13. The Law of the PRC on Chinese-Foreign Joint Ventures, art. 13, Renmin Ribao, July 9, 1979, reprinted in 1 China's Foreign Economic Legislation 1 (1982) (adopted at the Second Session of the Fifth National People's Congress on July 1, 1979, promulgated on July 8, 1979) [hereinafter cited as Joint Venture Law]. 
enterprises, and decide on the distribution of profits and the budget and final account of the revenue and expenditures of the enterprises.

(6) To hire or dismiss employees of the enterprises, adopt wage, reward and allowance systems which the enterprises deem suitable and give awards or punishment to the employees.

(7) To adopt, in accordance with the stipulations in contracts and regulations, necessary measures to improve and reform production technology, increase the variety of colors and designs, raise output and improve quality of the products. Funds accumulated by the enterprises can be used to purchase fixed assets and expand the scope of production and management.

These areas of decisionmaking power enjoyed by the joint venture and cooperation enterprises are now present in China's laws.

\section{Attraction of Foreign Investors}

China will do its best to create favorable investment conditions and provide facilities for foreign investors. There are many problems in this respect. Some problems of interest to foreign investors are explained as follows:

\section{The Market Problem}

Does China have any rules on overseas sales of products turned out by a joint venture and on reciprocal trade as a precondition for approving the establishment of a joint venture? Are there definite rules regarding the proportion of sales to be directed to the domestic and international markets? The answer is "no." China intends to have most joint venture products sold abroad to earn more foreign exchange. But China also allows some of the products to be sold in the domestic market. The ratio between products for the domestic market and those for export can be decided by either side of the joint venture enterprise through discussion in light of concrete conditions. The export rate of products which are in short supply in the domestic market may be lower, but the export rate of products which are not urgently needed or are in excessive supply in the domestic market should be higher. All or most of the products produced for the foreign market will be exported. Presently, the highest export rate for government approved joint venture products is 80 to $100 \%$, while the lowest export rate is approximately $20 \%$. In deciding on the export rate of products, it is important to ensure that the enterprises have enough foreign exchange to pay the foreign investors their share of the profits, to pay wages to foreign employees and to purchase necessary materials in the international market. In examining and approving a proposed joint venture, it is also 
necessary to take into consideration the abilities of the proposed enterprise to secure enough foreign exchange for its own needs. In other words, the balance of foreign exchange in the enterprises must be maintained.

\section{The Problem of Purchase and Sales Prices}

What about the purchase price of the materials, water, electricity and gas supplied to the joint ventures? What about the sales price of the products of these enterprises? Generally speaking, joint ventures can purchase goods and materials in the domestic market with renminbi at current domestic prices. Since there is a great discrepancy between the domestic allocation price and the price in the international market for certain precious metals used in production (e.g., gold, silver and platinum), and some nonferrous metals (e.g., aluminum, lead, zinc and tin), as well as petroleum, coal and timber, the price in the international market must be taken into account by both the purchaser and seller in fixing prices.

These materials can be purchased with renminbi and foreign exchange, depending on the negotiation. Joint ventures which need large quantities of such materials in production, as well as products which are targeted for the domestic market, may be given special consideration. With the approval of certain departments, such materials for the production of goods sold domestically can be purchased at domestic prices. Water, electricity and heat for these enterprises and oil for their transport vehicles are also supplied at domestic prices. The prices of the export or import goods managed by the foreign trade departments can be decided by the purchaser and seller with reference to the prices in the international market. The products of these enterprises for the domestic market generally must be sold at the current domestic price and paid for in renminbi. At the same time, the principle of fixing the price according to quality must be implemented. Moreover, in accordance with supply and demand, upon approval by the two sides through discussion, or by following relevant domestic regulations, the prices of some products can be fixed with reference to international prices; provided, however, that the prices are examined and approved by the responsible departments of the enterprises and the price control departments.

\section{The Problem of Taxation}

What tax liability does a joint venture incur? What preferential treatment may a joint venture enjoy with regard to taxation, and how can double taxation be avoided? In general, only two taxes are levied 
on joint venture enterprises, the unified industrial and commercial tax and the income tax of the enterprise. The former is calculated according to the sales volume of products and is included in production costs; the latter is levied according to profits. China's tax rate is not only lower than in the developed countries, but is also lower than in some developing countries. It is also a preferential rate compared to the rate levied against domestic state and collective enterprises. In addition to the unified industrial and commercial tax, state enterprises must turn over most of their profits to the state and may retain only a small portion for themselves. Collective enterprises and some state enterprises which are being reformed, in addition to the unified industrial and commercial tax, must pay a $50 \%$ income tax on profits of the enterprises.

In addition, joint venture enterprises are granted the following preferential treatment in the levying of taxes. First, equipment and other materials, which foreign participants in joint ventures need to import for investment purposes according to the provisions of their contracts, or which they need to buy from abroad with cash for the running of the enterprises, can be exempted from import duties and unified taxation for industrial and commercial undertakings. If this equipment or material is later sold in the domestic market, however, it is necessary to pay the amount exempted from customs duties and taxation.

Second, all raw materials, subsidiaries, spare parts or packing materials imported for the manufacturing of exported goods are exempted from import duties and the unified taxation for industrial and commercial undertakings. Taxes, however, shall be levied on the byproducts produced and on some exported goods which are produced to be sold in the domestic market for certain purposes. Some exported merchandise produced by joint ventures which earns relatively little foreign exchange can be exempted, with the approval of the Ministry of Finance, from the unified taxation for industrial and commercial undertakings according to the relevant regulations of the PRC. In addition, China is willing, through consultation, to conclude an agreement to avoid dual taxation with some countries which have recurring economic exchanges with China. At present, such consultations are underway with some countries and several agreements have been separately concluded.

\section{Laborers' Wages}

Some foreign participants in joint ventures have asked why China pays lower wages to its staff and workers than what is actually paid by the joint ventures. The answer is that the wages (or labor fees) of the 
Chinese staff and workers employed by joint ventures include two aspects. One is the actual pay to the staff and workers. The other is labor insurance, public health services, state subsidies for housing and traffic expenses, allowances for heating facilities and family reunions, and state subsidies for balancing the market prices of grain, edible oils and non-staple foods, as well as expenses for social welfare and culture. This is equivalent to one-third of the amount of actual pay. It has been stated that of the expenses, labor insurance accounts for $11 \%$, public health services for $6 \%$ and various subsidies for the staff of workers for $83 \%$. Of these subsidies, rent allowances account for $65 \%$, payments for balancing the market prices of grain, edible oils and non-staple food constitute $16 \%$, and the remaining $19 \%$ represents other allowances. These expenses are paid by the state to the staff and workers in various forms. Thus, it is quite reasonable for the Chinese participants in joint ventures to hand over a portion of their expenses to the state. The total sum of wages of the Chinese staff and workers in joint ventures, which includes the aforementioned aspects, is still much lower than that in foreign countries.

\section{Charges for Renting Land for Joint Venture Sites}

How is the standard of charges for the use of sites fixed and calculated? There is no uniform national standard charge for land used by joint ventures. This will be decided by the provincial, municipal and autonomous regional people's governments where the joint ventures are located. The charges can be fixed according to uses, geographical surroundings and conditions, expenses for acquisition of land and according to the actual needs of the joint ventures. In the remote areas where industry is underdeveloped, or in those trades in which investment profits are low, the charges for land to be used by the investors can be lowered. In uncultivated areas, if the land is utilized for agriculture and husbandry, rent charges can be considerably reduced. If some old factory sites are used for running joint ventures, the charges can be fixed according to the location of the site, the scope of development and the condition of public facilities. Some old factories are large and in a state of disrepair. If so, a discount can be given on land rentals to the joint ventures. China must do everything possible, however, to make things fair and reasonable. The land to be used for joint ventures can be used as an investment by the Chinese participants, or it can be rented.

The basic principles and policies mentioned above were embodied in the Law of the PRC on Chinese-Foreign Joint Ventures and in other laws before the two comprehensive documents were published in 1982 . Moreover, these policies have been consecutively enacted in additional 
laws and regulations, e.g., the regulations for the implementation of the Law of the PRC on Chinese-Foreign Joint Ventures, which includes 118 articles in sixteen chapters; it entered into force on September 20, $1983 .{ }^{14}$

\section{Substantive Laws}

\section{A. Joint Venture Law}

The Law of the PRC on Joint Ventures Using Chinese and Foreign Investment (the Joint Venture Law), promulgated on July 8, 1979, constitutes the first substantive turning point relating to foreign capital since the establishment of the PRC, as well as a major symbol of China's policy of opening its doors to the outside world. ${ }^{15}$

\section{Contribution and Equity Structure}

The "joint" character or feature of the law is embodied in the equity structure. Article 4 of the Joint Venture Law requires that in the registered capital of a joint venture, the proportion of the investment contributed by the foreign participant shall not be less than $25 \% .^{16}$ There is no restriction, however, on foreign investment over $50 \%$ of the total. The proportion of foreign capital is fixed through negotiation by the participants. ${ }^{17}$ Consequently, all profits, risks and losses of the venture are shared by the parties in proportion to their contributions to the registered capital. ${ }^{18}$

Each party to a joint venture may contribute, inter alia, cash, capital, goods and industrial property rights as its investment in the venture. On the foreign investor's side, the technology or equipment contributed by any foreign participant as an investment must be truly advanced and appropriate to China's needs. In the event of a loss suffered by the Chinese venturer, due to intentional provision of outdated technology or equipment by the foreign contributor, compensation must be paid for the loss. ${ }^{19}$ Consequently, how are the terms "truly advanced" or "world standard" as mentioned in the present law to be interpreted, and by whom are they to be evaluated? Generally, these standards contemplate technology that is up-to-date, dependable and practicable in China. Such technology must enable factories to turn out

14. See Jingii Ribao (Economic Daily), Sept. 27, 1983.

15. Joint Venture Law, supra note 13.

16. Id. art. 4.

17. See Answers, supra note 6, at 3,12 .

18. Joint Venture Law, supra note 13 , art. 4 , II 3.

19. Id. art. 5, Iा 1-2. 
products that are competitive in the international market. In other words, the technology or equipment must enable factories to produce better products and greater quantities while reducing the cost and consumption of raw and other materials and energy. The Ministry of FERT organizes groups of experts to examine and evaluate the technology offered by the foreign participant as part of the investment in the project. ${ }^{20}$

The investment contributed by the Chinese participant may include the use of a land site for the joint venture during the period of its operation. In the case where land use is not contributed by the Chinese participant, the joint venture shall pay the Chinese Government for land use. ${ }^{21}$ Land use charges are fixed and calculated by the people's government of the province, municipality or autonomous region where the joint venture is located in light of the specific purpose, duration and infrastructure requirements of the enterprise.

If the site is leased, payment is generally calculated by the size (square meters per year) and is paid on a yearly basis starting on the date the site is used. If the period for using the site exceeds six months in the first calendar year, payments are made semi-annually; if less than six months, payment is exempted. Joint ventures engaged in agriculture and animal husbandry may pay a certain percentage of their gross income for the use of the site if the provincial, municipal or autonomous regional governments so agree. ${ }^{22}$ In general, the actual siteuse fees in China are less than rates in neighboring countries. ${ }^{23}$ If the use of a site is contributed as part of the investment by the Chinese participant, such contribution is calculated on the basis of rent that would have been payable for the use of a similar site. ${ }^{24}$

The various contribution formulae mentioned above shall be specified in the contracts concerning the joint venture or in its articles of association, and the value of each contribution (excluding site valuation) shall be ascertained by the parties to the venture through joint assessment. $^{25}$

20. See Answers, supra note 6, at $3,12$.

21. Joint Venture Law, supra note 13 , art. 5 , 13.

22. See Answers, supra note 6, at 7, 14. The foreign investor cannot purchase and own land in the PRC because the PRC is a socialist state. According to the Constitution, all land is owned by the State or by collectives. XIANFA (Constitution), art. 10 (PRC).

23. See Some Aspects of China's Work in Economy, Trade and Law at 6, Remarks of Ren JianXin, Director of the Legal Affairs Department, China Council for the Promotion of International Trade, before the Conference on Selling Technology to China, National Council for the United States-China Trade, in Wash., DC (Dec. 5, 1979) [hereinafter cited as Ren JianXin's Remarks].

24. See supra note 22.

25. Joint Venture Law, supra note 13 , art. 5, If 4. 


\title{
2. Authorization, Registration and Protection
}

The initial contract and articles of association of a joint venture comprise the venture's constitution. As a sovereign state, China requires all foreign participants who want to form joint ventures with Chinese participants within the territory of the PRC, to get formal approval and authorization from the Chinese Government: ${ }^{28}$

\begin{abstract}
A joint venture shall apply to the Foreign Investment Commission of the People's Republic of $\mathrm{China}^{27}$ for authorization of the agreement and contracts concluded between the parties to the venture and articles of association of the venture formulated by them, and the commission shall authorize or reject these documents within three months. When authorized, the joint venture shall register with the General Administration for Industry and Commerce of the People's Republic of China and start operation under license. ${ }^{28}$
\end{abstract}

A joint venture is regarded as having been officially established on

26. Id. art. 1.

27. The exercise of the approval authority of the State Foreign Investment Commission has been transferred to a new ministry. See Decision by the Standing Committee of the National People's Congress on the Exercise of the Approval Authority of the Former State Foreign Investment Commission by the Ministry of Foreign Economic Relations and Trade, Standing Committee of the Fifth National People's Congress, 26th Meeting (Mar. 5, 1983). At its 22d meeting, the Standing Committee decided that the State Foreign Investment Commission should be merged into the Ministry of Foreign Economic Relations and Trade (FERT). See Resolution on Restructuring the State Council, Standing Committee of the Fifth National People's Congress, 22d Meeting. Thus, the approval authority formerly exercised by the State Foreign Investment Commission in accordance with provisions of the Law of the PRC on Joint Ventures Using Chinese and Foreign Investment and other relevant laws and regulations concerning foreigners would henceforth be exercised by the Ministry of FERT. See Renmin Ribao, Mar. 6, 1983, at 4 .

FERT, however, retained the power to delegate to the people's governments of provinces, municipalities and autonomous regions or other ministries, commissions and administrations under the State Council, the authority to examine and approve projects that conform to the following two conditions:

1. The projects require no additional state allocations of raw and other materials, do not affect the national balance on matters of fuel, power and transportation and produce no products that take up the state export quotas;

2. The total investment of a project does not exceed U.S. $\$ 5$ million in Liaoning Province and the municipalities of Beijing, Shanghai and Tianjin and U.S. \$3 million in other provinces, autonomous regions and under other ministries, commissions and administrations under the State Council, with the exception of Guangdong and Fujian Provinces where no limit is imposed on such investment, and the Chinese investment is procured by drawing on the funds (including foreign exchange) owned by local governments, departments under the State Council or the enterprise involved in the project. Id.

28. Joint Venture Law, supra note 13, art. 3. 
the day when its license is issued. After that date, all of its "legitimate production and business shall be protected by the Laws of the PRC."29 Furthermore: "The Chinese Government protects, by the legislation in force, the resources invested by a foreign participant in a joint venture and the profit due to him pursuant to the agreements, contracts and articles of association authorized by the Chinese Government as well as his other lawful rights and interests." 30

As a basic matching obligation for such protection and rights, a joint venture, including the foreign participant within Chinese territory, "shall be governed by the laws, decrees and pertinent rules and regulations of the PRC." 31 Both of the joint venture participants must "comply with and implement the agreements, contracts and articles of association signed by the participants, reporting through the joint venture to the proper authorities the joint venture's construction, production and operations, accepting the supervision and administration by proper Chinese authorities and paying taxes due."32

29. Procedures of the PRC for the Registration and Administration of Chinese-Foreign Joint Ventures, art. 5, Renmin Ribao, July 27, 1980, reprinted in 1 ChINA's ForeigN Economic Legislation 13 (1982) (promulgated by the State Council of the PRC on July 26,1980 ) [hereinafter cited as Regulations on JV Registration].

30. Joint Venture Law, supra note 13, art. 2 , I 1.

31. Id. $\pi 2$.

32. See Answers, supra note 6, at 5, 13. For example, article 10 of the regulations provides:

The General Administration for Industry and Commerce of the PRC and the Administrative Bureaus for Industry and Commerce in the provinces, municipalities and autonomous regions are authorized to supervise and inspect the joint ventures using Chinese and foreign investment in the areas they govern. In cases of violations of the present regulations, the violator shall be given a warning or be fined in accordance with the varying degrees of seriousness in each specific case.

Regulations on JV Registration, supra note 29, art. 10.

Article 13 of the Regulations of the PRC on Labor Management in Chinese-Foreign Joint Ventures provides: "Joint ventures must implement the relevant rules and regulations of the Chinese Government on labor protection and ensure safety in production and civilized production. The Labor Management Department of the Chinese Government is authorized to supervise and inspect their implementation." Renmin Ribao, July 27, 1980 (promulgated by the State Council of the PRC on July 26, 1980).

Article 12 of the Income Tax Law of the PRC Concerning Chinese-Foreign Joint Ventures provides: "The tax authorities have the right to investigate the financial affairs, account books and tax situation of any joint venture. Such joint venture must make reports according to the facts and provide all relevant information and shall not refuse to cooperate or conceal the facts." See infra note 61 . The tax authorities are authorized by article 14 to exercise their discretion in light of the circumstances to impose a fine on a joint venture that has violated the provisions of this law. In dealing with a joint venture that has evaded or refused to pay tax, the tax authorities, in addition to pursuing the tax payment, may impose a fine of up to but not exceeding five times the tax due in accor- 


\section{Management Responsibility}

After the official establishment of a joint venture, the efficient management and direction of the venture must be discussed. The law provides:

A joint venture shall have a board of directors with a composition stipulated in the contracts and the articles of association after consultation between the parties to the venture, and each director shall be appointed or removed by his own side. The board of directors shall have a chairman appointed by the Chinese participant and one or two vice-chairmen appointed by the foreign participant(s). In handling an important problem, the board of directors shall reach decisions through consultation by the participants on the principle of equality and mutual benefit. ${ }^{33}$

Some foreign investors may be concerned about the clause providing for the appointment of the chairman by the Chinese side, regardless of the extent of the foreign equity participation. Suspicions may arise that the decisionmaking power and daily management rights which should be shared by both participants will be diluted. Anxiety over this issue is unwarranted. First, the article above expressly stipulates that any important decision of the board shall be reached "through consultation by the participants on the principle of equality and mutual benefit." Second, the "Chinese chairman will enjoy the advantage of easy approach to the Chinese people either vertically or horizontally, thus benefitting the joint venture as a whole." ${ }^{4}$ Third, section 3 of the same article provides: "The president and vicepresident(s) (or the general manager and assistant general manager(s) in a factory) shall be chosen from the various parties to the joint venture." 35 There is no restriction prohibiting the foreign participant from

dance with the seriousness of the case. Cases of gross violation shall be handled by the local people's courts in accordance with the law. See id.

Officials must strictiy abide by due process of law while supervising, inspecting or investigating the matter. For instance, "[o]fficials sent by tax authorities when investigating the financial, accounting and tax affairs of a joint venture, shall produce identification cards and undertake to keep secret" the information discovered. Rules for the Implementation of the Income Tax Law of the PRC Concerning Chinese-Foreign Joint Ventures, art. 27, Renmin Ribao, Dec. 15, 1980 reprinted in 1 China's Foreign EcoNomic Legislation 45 (1982) (approved at the State Council of the PRC on Dec. 10, 1980 and promulgated by the Ministry of Finance on Dec. 14, 1980), [hereinafter cited as JV Tax Law Implementation Rules].

33. Joint Venture Law, supra note 13, art. 6, I1.

34. Ren JianXin's Remarks, supra note 23 , at 4.

35. Joint Venture Law, supra note 13, art. 6, 13. 
acquiring the position of president or general manager. Fourth, a new interpretation from FERT directs that the composition of the board of directors and the number of its members, as well as the appointments of general manager and deputy managers, shall be decided upon through consultation by all the participants in a joint venture, taking into account the shares of investment of each participant. ${ }^{36}$ Fifth, some recent cases have already sufficiently indicated flexibility and generosity in the application of the aforesaid legal provisions.

China-Schindler Elevator Co., Ltd. (JVC) involved a joint venture company incorporated in accordance with the relevant laws of China. The Chinese participant contributed equity of $75 \%$; the foreign participants combined (Schindler Co. and JS Co.) contributed $25 \%$. The board of directors consisted of eight members, with the chairman appointed by the Chinese participant, the only vice-chairman appointed by Schindler Co., five directors appointed by the Chinese participants and the remaining director appointed by JS Co. The articles of association provide:

§ 8.6 Business at meetings of the board of directors will proceed in accordance with the agenda, each matter arising to be discussed appropriately and put to a decision by way of resolution.

§ 8.7 Each board member . . . shall have one vote and any resolution put to a meeting for a decision shall be passed if approved.

$\S$ 8.7.1 In the case of a resolution relating to the issue or amendment of board instructions and appointment of (Chief) Officers of the JVC by a majority of twothirds, which must include the vote of the Vice-Chairman or the director appointed by JS . . . .

$\S$ 8.7.2 In the case of a resolution relating to other business, by a simple majority which must include the vote of the Vice-Chairman or the director appointed by JS $\ldots .^{37}$

Although the equity participation, director membership and right to vote shared by the foreign participants is only $25 \%$, the voting rules of Section 8.7.1 and Section 8.7.2 actually give the foreign participant a

36. See Answers, supra note 6, at 4, 12.

37. Articles of Association of China-Schindler Elevator Co., Ltd. (JVC), China Economic News (Hong Kong), Supp. No. 3, Apr. 14, 1980, at 2-5, 8-10; cf. Agreement on the Establishment of a Joint Venture Elevator Company in the People's Republic of China, China Economic News (Hong Kong), Supp. No. 2, Apr. 7, 1980, at 2, 6, 7, 10. [hereinafter cited as Joint Venture Agreement]. 
right of veto at the board meeting. "In handling an important problem, the board of directors shall reach decision through consultation by the participants on the principle of equality and mutual benefit,"38 even though the foreign participants are merely a one-quarter minority.

The Great Wall Hotel of Beijing is a joint venture of general partnership, formed by the Beijing Branch of the China International Travel Service (CITS), together with a foreign participant, the E-S Pacific Development and Construction Company (ESPDC), for the purpose of building and operating a modern, international, first-class hotel of approximately 1,000 rooms in Beijing.

According to the "joint venture contract," CITS shall offer the construction sites as equity participation of $51 \%$, while ESPDC shall be responsible for financing the required total project cost as equity participation of $49 \%$. The total financing, including principal and interest, will be paid back in periodic installments out of the gross revenue of the hotel over a period of ten years, commencing upon the opening of the hotel. ${ }^{39}$

After the completion of the construction of the hotel, both parties will jointly operate the hotel for ten years. During these ten years of operation, both parties shall share the responsibility for operating the hotel and each shall share the hotel's profits and losses in proportion to its participation.

The period set for the joint operation by both parties is ten years, commencing with the formal opening date of the hotel. When the period comes to an end, all of the hotel accounts for profits or losses shall be settled and paid. Thereafter, the joint venture relationship of both parties shall terminate; the total assets, rights and interests of the hotel shall be owned solely by CITS without further compensation to ESPDC. ${ }^{40}$

The management responsibility of the present joint venture is provided for as follows:

The board [of directors] will consist of seven members with four members designated by CITS and three members designated by ESPDC . . . . In dealing with major issues, both parties shall make decisions in accordance with the principle of equality, mutual benefit and friendly consultation. . . . During the period of joint operation after the hotel has opened offi-

38. Joint Venture Law, supra note 13, art. 6, II 1.

39. See Joint Venture Contract for the Construction and Operation of the Great Wall Hotel of Beijing (Extracts), ch. 11, China Economic News (Hong Kong), Supp. No. 4, Apr. 21, 1980, at 2, 10-11.

40. Id. 
cially for business, the daily operation and management of the hotel shall be run by the manager and the deputy manager under the supervision of the board. During the first three years, ESPDC's designee shall be the manager and CITS' designee shall be the deputy manager. At any time during this period, if CITS' deputy manager becomes capable of managing all facets of the hotel's operations, ESPDC shall turn over the manager's position to the deputy manager. In any event, this transfer of authority shall occur within three years. At the time of transfer, ESPDC shall designate the deputy manager. The hotel may set up various departments under the manager and the deputy manager as required. Within the first three years, all the chief positions of the various staff functions shall be taken by designees of ESPDC. CITS' designees shall take all the appropriate deputy positions. During this period, ESPDC should transfer the relevant chief positions to any deputies as soon as they have become capable of the management work in the area. By the end of the third year, all the chief positions of the various departments should be assumed by designees of CITS. ${ }^{41}$

There are two points worth noting. First, unlike the prior cases of China-Schindler, decisions on major issues in this case shall be made by "friendly consultation" rather than "by way of resolution." 42 This means that no decisions should be made without the full consensus of both participants at the board meetings. Second, all chief positions of daily operation and management, including manager and various department heads, are to be allocated to designees of the foreign participant during the first three years.

The scope of the aforesaid "important problem" and "major issues" to be acted upon by the board of directors, pursuant to the joint venture's "articles of association," is explicitly construed in the Joint Venture Law itself. They include fundamental issues such as expansion projects, production and business programs, the budget, distribution of profits, plans concerning manpower and pay scales, the termination of business and the appointment and function of management personnel. ${ }^{43}$ Decisions on revising the articles of association, terminating or disbanding the joint venture, transforming capital or merging the joint venture with other economic organizations must be made by unanimous vote at a meeting of the board of directors. Decisions on other

41. Id. at 5-7, 12-13.

42. Cf. supra note 37 and accompanying text.

43. Joint Venture Law, supra note 13, art. 6, If 2. 
matters may be carried by two-thirds or simple majority vote. ${ }^{44}$

The general manager executes the decisions adopted by the meeting of the board of directors and is responsible for the day-to-day operations and administration of the joint venture. Within the limit of the board's authorization, whether or not he is a foreigner, the general manager may conduct negotiations and sign documents with other organizations, appoint and dismiss his subordinates and exercise other powers given to him by the board of directors. In handling important affairs, however, the general manager must consult with his deputies. ${ }^{45}$

\section{Labor and Wages}

Labor costs are a crucial issue in a joint venture because they directly impact on the investors' net profits. Plans concerning manpower and pay scales are an essential item on the board of director's agenda. ${ }^{46}$ Moreover, even before the formation of the board and the designation of the manager, the basic employment procedures, including the discharge of the workers and staff members of a joint venture, shall be stipulated according to law in the agreement or contract directly concluded between the investors. ${ }^{47}$

As a socialist state of laborers and as a developing country in need of foreign investment, China must simultaneously address various concerns. It must provide for the fair treatment of workers employed by joint ventures, while at the same time provide a reasonable rate of return on profits to encourage foreign participation and investment. As a result of these concerns, regulations ${ }^{48}$ have been promulgated.

All matters pertaining to employment, dismissal and resignation of workers and staff members, tasks of production and other work, wages and awards, working hours and vacation time, and labor discipline shall be stipulated in the labor contracts signed. ${ }^{49} \mathrm{~A}$ labor contract is to be signed by both the joint venturers and the trade union organization formed in the joint venture. Small joint ventures may undertake contracts with individual workers and staff members. According to the regulations, both kinds of contracts must be submitted to the labor management department of the provincial, autonomous regional or

44. See Answers, supra note 6 , at $4,12$.

45. Id.

46. See Joint Venture Law, supra note 13, art. 6, Il 2.

47. Id. ๆ 4.

48. Provisions of the PRC for Labor Management in Chinese-Foreign Joint Ventures, reprinted in 1 China's Foreign Economic Legislation 20-23 (1982) (promulgated by the State Council of the PRC and effective as of July 26, 1980) (hereinafter cited as Provisions for JV Labor Management].

49. Id. art. 2. 
municipal people's government for approval. ${ }^{\text {so }}$

In order to ensure high productivity and efficiency, a joint venture may recruit qualified, skilled workers depending on the requirements of production and management. Local labor authorities will recommend suitable workers. ${ }^{51}$ All the workers and staff members of a joint venture, either recommended by the authorities in the locality in charge of the joint venture or the labor management department, or recruited by the joint venture itself with the consent of the labor management department, will be tested and, based on their qualifications, will be chosen by the joint venture. Furthermore, joint ventures may run workers' schools and training courses for the training of managerial personnel and skilled workers. ${ }^{52}$

When changes in production and technical conditions of the joint venture result in a surplus of workers or staff members, the joint venture may dismiss the employees if, after training, they fail to meet the new requirements and are not suitable for other work. In such an event, however, the labor contract requires that the joint venture provide compensation to these workers. In addition, the dismissed workers and staff members will receive assignments for other work from the authorities in charge of the joint venture or the labor management department. . $^{3}$

The joint venture may, according to the degree of seriousness of the case, take action against those workers or staff members whose violations of rules and regulations of the enterprise are detrimental to the venture. If punishment by dismissal is to be imposed, it must be approved by the authorities in charge of the joint venture and the labor management department. ${ }^{\text {st }}$

Provisions for joint venture labor management state that wage standards, the forms of wages paid and bonus and subsidy systems are to be discussed and decided upon by the board of directors. ${ }^{55}$ Decisions on these matters may be determined freely, with the following exceptions:

(1) The wage level of the workers and staff members in a joint venture will be set at 120 to $150 \%$ of the real wages of the workers and staff members of state-owned enterprises of the same trade in the locality. ${ }^{\text {s6 }}$

50. Id

51. See Answers, supra note 6, at 7, 14.

52. Provisions for JV Labor Management, supra note 48, art. 3 .

53. Id. art. 4.

54. Id. art. 5.

55. Id. art. 9.

56. Id. art. 8. 
(2) The bonuses and welfare funds drawn by the joint venture from the profits must be used as bonuses, awards and collective welfare and should not be misappropriated..$^{57}$

(3) A joint venture must pay for the Chinese workers' and staff members' labor insurance, medical expenses and various other government subsidies in line with the standards prevailing in state-owned enterprises. ${ }^{88}$ Subsidies established by the state include price subsidies for staple and non-staple food and edible oils, rent, commuting fees, heating expenses, home leave allowances and expenses for cultural and recreational activities. ${ }^{58}$

\section{Taxation}

Taxation is another crucial area affecting foreign investors' net profits. The Joint Venture Law provides:

The net profit of a joint venture shall be distributed between the parties to the venture in proportion to their respective shares in the registered capital after the payment of a joint venture income tax on its gross profit pursuant to the tax laws of the People's Republic of China and after the deductions therefrom as stipulated in the articles of association of the venture for the reserve funds, the bonus and welfare funds for the workers and staff members and the expansion funds of the venture. ${ }^{80}$

Income tax shall be paid in accordance with the provisions of the Joint Venture Tax Law by Chinese-foreign joint ventures located in the PRC on all income from production and business operations as well as on other income. ${ }^{81}$ The taxable income of a joint venture shall consist of the gross income of the fiscal year reduced by deductible costs, expenses and losses. ${ }^{.2}$

The income tax rate on joint ventures is $30 \%$. In addition, a local income tax of $10 \%$ of the assessed income tax shall be levied. ${ }^{.3}$ For example, if a joint venture that has taxable income of $\$ 100,000,000$ : (i)

57. Id. art. 10.

58. Id. art. 11.

59. See Answers, supra note 6, at 7, 15.

60. Joint Venture Law, supra note 13 , art. 7 , II 1.

61. The Income Tax Law of the PRC Concerning Chinese-Foreign Joint Ventures, Renmin Ribao, Sept. 11, 1980, art. 1, $\S 1$, reprinted in 1 China's Foreign Economic Legislation 36 (1982) (adopted at the Third Session of the Fifth National People's Congress and promulgated on Sept. 10, 1980) [hereinafter cited as JV Tax Law].

62. JV Tax Law, supra note 61, art. 2.

63. Id. art. 3. 
the income tax to be paid to the state would be $\$ 100,000,000$ times $30 \%$, or $\$ 30,000,000$; and (ii) the local income tax to be paid to the local authorities would be $\$ 30,000,000$ times $10 \%$, or $\$ 3,000,000$. The net profit would be $\$ 100,000,000$ minus $(\$ 30,000,000$ plus $\$ 3,000,000)$, or $\$ 67,000,000$. This is a comparatively lower tax rate than in other parts of the world.

Due to special conditions, such as the ratio between investment and profit, income tax rates on joint ventures that develop petroleum, natural gas and other resources are to be stipulated separately. ${ }^{64}$

China makes available a series of special reductions and exemptions from income tax; these are discussed below:

(1) A joint venture equipped with up-to-date technology by world standards may apply for a reduction of or an exemption from income tax for the first two to three profit-making years. ${ }^{68}$ The meaning of the term "up-to-date technology by world standards" has been interpreted by the Ministry of FERT. ${ }^{68}$ A newly established joint venture scheduled to operate for a period of ten or more years, upon approval by the tax authorities of an application filed by the venture, shall be exempted from income tax in the first and second profit-making years and allowed a $50 \%$ reduction of income tax in the third to fifth years. ${ }^{87}$

(2) With the approval of the Ministry of Finance of the PRC, joint ventures engaged in relatively low-profit operations such as farming and forestry, or joint ventures established in remote, economically underdeveloped regions may be allowed a 15 to $30 \%$ reduction in income tax for an additional ten years following the initial period of exemption and reduction specified in the preceding paragraph. ${ }^{88}$

(3) A foreign participant who reinvests any part of his share of the net profit within Chinese territory may apply for a partial refund of the tax paid. ${ }^{68}$ Specifically, a foreign joint venturer who reinvests his share of net profits obtained from the venture for a period of not less than five years shall, upon approval by the tax authorities, be refunded $40 \%$ of the income tax already paid on the reinvested portion. If he withdraws the investment within five years, however, he must repay

64. Id. art. $3, \S 2$.

65. Joint Venture Law, supra note 13, art. 7, I 2.

66. See supra note 20 and accompanying text.

67. See Decision for the Amendment of the Income Tax Law of the PRC Concerning Joint Ventures with Chinese and Foreign Investment, Renmin Ribao, Sept. 3, 1983, (adopted at the Second Session of the Standing Committee of the Sixth National People's Congress on Sept. 2, 1983).

68. JV Tax Law, supra note 61 , art. $5, \S 2$.

69. Joint Venture Law, supra note 13, art. 7, I 3. 
the refund. ${ }^{70}$

(4) There may be a reduction of or exemption from the local income tax for special circumstances; this is determined by the people's government of the province, autonomous region or municipality in which the joint venture is located. ${ }^{71}$

(5) According to the Individual Income Tax Law of the PRC and the "Rules for the Implementation" of the same law, dividends and extra dividends as a category of income received from sources within the territory of China by individuals, whether payment is made in China or elsewhere, shall be taxed under the provisions of the tax law. But, as an exception, "dividends and extra dividends received from Chinese-foreign joint ventures shall be exempted from taxation."72

(6) In most countries of the world, the interest on savings deposits is considered a category of individual income and consequently must be taxed. According to China's Individual Income Tax Law, however, the interest on savings deposits in the state banks and credit cooperatives of the PRC, although also considered a category of individual income, "shall be exempted from individual income tax."7s

The Joint Venture Law explicitly stipulates: "A foreign participant shall receive encouragement for depositing in the Bank of China any part of the foreign exchange which he is entitled to remit abroad."74 Furthermore, the Rules of the Individual Income Tax Law provide:

interest on savings deposits in the state banks and credit cooperatives of the People's Republic of China mentioned in article 4 , section 2 of the Tax Law includes interest on savings deposits in renminbi and foreign currency and interest on savings deposits in other banks entrusted by the state banks. ${ }^{75}$

70. JV Tax Law, supra note 61 , art. 6 .

71. Id. art. $3, \S 2$ (Rules for Implementation of the Income Tax Law of the PRC Concerning Chinese-Foreign Joint Ventures).

72. See id. arts. 1 \& 2; The Individual Income Tax Law of the PRC, Renmin Ribao, September 10, 1980, reprinted in 1 China's Foreign Economic Legislation 75 (1982) (adopted at the Third Session of the Fifth National People's Congress and promulgated on Sept. 10, 1980) [hereinafter cited as Individual Income Tax Law]. See also Rules for the Implementation of the Individual Income Tax Law of the PRC, Renmin Ribao, Sept. 15, 1980, art. 5, reprinted in 1 China's Foreign Economic Legislation 85 (1982) (approved by the State Council of the PRC on Dec. 10, 1980 and promulgated by the Ministry of Finance on Dec. 14, 1980) [hereinafter cited as Rules of Individual Income Tax Law].

73. Individual Income Tax Law, supra note 72 , art. $4, \S 2$.

74. Joint Venture Law, supra note 13, art. 10, ๆ 2.

75. Rules of Individual Income Tax Law, supra note 72 , art. $9, \S 1$. 
It is apparent, therefore, that all foreign participants can enjoy the same exemption of interest-income tax if they deposit their profits earned in the PRC in the Bank of China to earn further interest before repatriating the money. ${ }^{78}$

(7) Dividends from investments by individuals in local development companies in China shall also be exempted from taxation if no extra dividends are paid and if dividends are not higher than the interest on savings deposits in the state banks and credit co-operatives. ${ }^{77}$

(8) Losses incurred by a joint venture in a tax year may be carried over to the next tax year and offset against a corresponding amount from that year's income. Should the income in the subsequent tax year be insufficient to offset the losses, the balance may be offset against income in successive years, but not exceeding five years. ${ }^{78}$

(9) Income tax paid abroad by a joint venture or its branches on income earned outside of China may be credited against the amount of income tax to be paid by the head office by presenting a foreign tax payment receipt. The creditable amount, however, shall not exceed the tax payable on the income obtained abroad as computed in accordance with the tax rate prescribed by China's tax laws. ${ }^{79}$

(10) Additional methods for obtaining preferential tax treatment exist for joint ventures. The general framework of these preferential treatments has been set out in both the FERT Handbook Ministry ${ }^{80}$ and the policy speech of FERT's Vice-Minister Wei Yuming. ${ }^{81}$

In all, more than ten categories of reductions and exemptions contribute to push the potential ratio of net profits to taxable income over the $67 \%$ mark calculated above. ${ }^{82}$

\section{Exchange Control and Repatriation}

The policy and decree relating to foreign exchange in China has two goals. As a socialist state, China must exercise strict control on foreign exchange; as a developing country encouraging foreign investment, China must assist foreign participant-investors as much as possible. The Provisional Regulations for Exchange Control of the PRC (the Exchange Control Regulations) seek to reconcile these goals.

To strengthen exchange control, increase national foreign ex-

76. See Joint Venture Law, supra note 13 , art. 10, ๆ 2 .

77. Rules of Individual Income Tax Law, supra note 72, art. 9, § 2 .

78. JV Tax Law, supra note 61, art. 7.

79. JV Tax Law Implementation Rules, supra note 32, art. 32.

80. See Answers, supra note 6, at 6-7, 14.

81. See Wei's Speech, supra note 7 and accompanying text.

82. See supra notes $65-81$ and accompanying text. 
change income and economize on foreign exchange expenditures, in order to expedite the national economic growth and safeguard the rights and interests of the country, the PRC pursues a policy of centralized control and unified management of foreign exchange by the state. ${ }^{83}$ All foreign exchange income and expenditures, the issuance and circulation of various payment instruments in foreign currency, and the transfer of foreign exchange, precious metals and negotiable instruments in foreign denominations in and out of China are governed by these regulations. ${ }^{84}$ The circulation and use of foreign currency in the $\mathrm{PRC}$ is prohibited, as is the unauthorized sale or purchase of foreign exchange. ${ }^{85}$

The administrative organ which controls exchange in the PRC is the State General Administration of Exchange Control (SGAEC) and its branch offices. The specialized foreign exchange bank of the PRC is the Bank of China. No other financial institution is permitted to engage in foreign exchange without SGAEC approval. ${ }^{86}$ The regulations do, however, also guarantee full protection to legal foreign exchange owners for the use, sale, deposit and remittance of exchange out of China. Chinese and foreign nationals and stateless persons residing in Chira, for example, are permitted to keep in their own possession foreign exchange already in China. ${ }^{87}$

Foreign exchange remitted or brought into China from foreign countries or from Hong Kong or Macao by foreign nationals coming to China, by overseas Chinese and Hong Kong and Macao compatriots coming for a short stay, by foreign experts, technicians, staff members and workers engaged to work in domestic organizations, and by foreign students and trainees, may be kept in their own possession, sold to or deposited with the Bank of China, or remitted and taken out of China. ${ }^{88}$

Enterprises with overseas Chinese capital and enterprises with foreign capital, as well as foreign partners in Chinese-foreign joint ventures, may apply to the Bank of China to remit abroad their net after tax profits and legitimate earnings. ${ }^{8 \theta}$

As a general principle, the Joint Venture Law requires that a joint

83. See Interim Regulations on Foreign Exchange Control of the PRC, chs. 1-7 (1980), reprinted in 1 China's Foreign Economic Legislation 118-29 (1982) [hereinafter cited as Exchange Control Regulations].

84. Id. art. 1, II 2.

85. Id. art. 4, II 2.

86. Id. I 3 .

87. Id. art. 14, १ 1 .

88. Id. art. 18.

89. Id. art. 24 , II 1 . 
venture shall conduct its foreign exchange transactions in accordance with the Foreign Exchange Regulations of the PRC. Furthermore, the venture must open an account with the Bank of China or a bank approved by the Bank of China. In a specific provision, the Joint Venture Law strongly confirms this notion and provides:

[t]he net profit which a foreign participant receives as his share after executing his obligations under the pertinent laws and agreements and contracts, the funds he receives at the time when the joint venture terminates or winds up its operations, and his other funds may be remitted abroad through the Bank of China in accordance with the foreign exchange regulations and in the currency or currencies specified in the contracts concerning the joint venture. ${ }^{80}$

According to the Exchange Control Regulations, in daily business transactions, all foreign exchange receipts of enterprises with overseas Chinese capital, enterprises with foreign capital, as well as Chineseforeign joint ventures must be deposited with the Bank of China. In addition, all foreign exchange disbursements must be paid from the entity's foreign exchange deposit accounts." Consequently, in remitting net profits abroad, application may be made to the Bank of China to debit the foreign exchange deposit accounts of the enterprises concerned. ${ }^{92}$ In transferring foreign exchange capital abroad, the enterprise should apply to SGAEC or to one of its branch offices to debit the foreign exchange deposit accounts.

In accordance with the Joint Venture Tax Law, when a foreign joint venturer remits its share of profits obtained from the venture abroad, an income tax of $10 \%$ of the remitted amount will be levied. ${ }^{93}$ Apart from this tax, and the others discussed above, there are no other tax restrictions. The next question is whether it is possible for China to suspend remittance of profits by a foreign partner in a joint venture because of difficulties China may have with its balance of international payments. The Ministry of FERT has answered this question definitively:

China will never stop a foreign participant in a joint venture from remitting abroad its share of profits even if the country should be struck by an imbalance in the international payments, for the legitimate rights and interests of foreign partici-

90. Joint Venture Law, supra note 13, art. 10, I 1.

91. Exchange Control Regulations, supra note 83, art. 22, in 1.

92. Id. art. 24 , \ 1.

93. JV Tax Law, supra note 61, art. 4. 
pants and their lawful profits are protected by the Law on Chinese-Foreign Joint Ventures and other laws, rules and regulations. ${ }^{94}$

\section{Expiration and Assets Disposition}

There are no inflexible restrictions on the length of time a joint venture may operate. A joint venture's duration may be agreed upon by the parties to the venture according to business circumstances. Upon expiration the period may be extended by agreement of the parties with the authorization of the Ministry of FERT. Applications for extensions must be made six months prior to the expiration of the contract. $^{98}$ In cases of heavy financial loss or the failure of a joint venturer to execute its obligations under the contract or articles of association, the contract may be terminated prior to the contract's expiration date by consultation and agreement of the parties and authorization from the Ministry of FERT. In the case of loss caused by breach of contract by a party to the venture, the financial responsibility shall be borne by the breaching party.98

At the expiration of the contract period or upon termination prior to the contract's expiration date, all participants to the joint venture will face the inevitable problem of disposing of the remaining assets of the venture. How are fixed assets and other materials to be disposed of? Upon dissolution of a joint venture, the foreign participant shall be paid according to his share of the investment on the basis of the fixed assets net value minus depreciation. If, for special reasons, the replacement cost of the fixed assets is used, complete replacement cost should be calculated first. The accumulated depreciation allowances up to the expiration or dismissal of the joint venture should then be worked out according to the complete replacement cost, and the deduction will consist of the depreciated replacement cost. This may be considered the basis for repayment to a foreign partner according to his share of investment.

Other transferred materials will be evaluated according to their respective cost or selling price, taking into consideration their different natures. ${ }^{97}$

In practice, there are many cases in which some preferential and generous treatment has been promised to the foreign participants in

94. See Answers, supra note 6, at 7-8, 15.

95. Joint Venture Law, supra note 13, art. 12.

96. Id. art. 13.

97. See Answers, supra note 6, at 9, 15. 
the future assessment and valuation of the dissolving joint venture's assets and interests. For example, the articles of association of ChinaSchindler Elevator Co., Ltd. (JVC) provide:

16.1 On the termination of the corporate existence of the JVC ... , the interests of Schindler and JS in the JVC shall be purchased by CCMC in accordance with the Joint Venture Agreement.

16.2 On the transfer of the interests of Schindler and JS to CCMC, CCMC shall pay Schindler and JS, in cash, an amount equivalent to the value of their respective participations in the JVC.

16.3 The value of the participations of Schindler and JS shall be based on the relevant proportion of the total value of participants' funds in the JVC to which shall be added an element to be agreed upon by negotiation to reflect the future profitability of the JVC.98

\section{Settlement of Disputes}

China welcomes foreign investment in order to accelerate its modernization program; therefore, it thus wishes to make the investment climate as warm as possible. At the same time, most of the foreign participants in joint ventures are honest businessmen who recognize that China is a socialist, sovereign state and willingly abide by the laws of the host country. But as the Chinese idiom warns, "teeth and tongue cooperate while eating, but occasionally conflict by chance." It is obviously necessary to stipulate in advance some reasonable principles of dispute settlement for joint venture participants.

Three types of disputes arise: (1) between joint venture participants, (2) between employers and employees and (3) between the joint ventures and other entities.

With respect to the first type of dispute, the Joint Venture Law provides that disputes arising between the parties to a joint venture that the board of directors cannot settle through consultation may be settled through mediation or arbitration by a Chinese arbitration agency or through arbitration by another arbitration agency agreed upon by the parties to the venture. ${ }^{99}$ As construed by the FERT Handbook, this provision means that disputes between the parties in a joint venture with regard to the interpretation or implementation of their

98. Articles of Association of China-Schindler Elevator Co., Ltd. (JVC), supra note 37, at 7, 12; cf. Joint Venture Agreement, supra note 37, at 3, 8.

99. Joint Venture Law, supra note 13, art. 14. 
agreement, contract and articles of association should be settled, whenever possible, through friendly consultation or mediation. Should such consultation or mediation fail, the cases can be submitted to the China Foreign Economic and Trade Arbitration Commission for arbitration under its arbitration procedures (these will be discussed infra). Cases may also be referred to an arbitral tribunal in the defendant's country or a third country chosen by both parties. If there are no arbitration clauses in the signed joint venture agreement nor in any written documents on arbitration, either party can bring the case before a court. ${ }^{100}$

Some foreigners have questioned whether China would allow a foreign partner to settle a dispute over investment through its agent and whether there would be a special court for ruling on commercial disputes. A foreign partner, as a party to a dispute, can either appear in person or by proxy before the China Foreign Economic and Trade Arbitration Commission or the court. A Chinese or foreign national may act as his proxy. When the case is brought before a Chinese court, however, a Chinese lawyer must accompany the foreign party in court. ${ }^{101}$

China has not yet considered setting up a special court for settling disputes over commercial and investment affairs. Such cases can be arbitrated or handled by the economic bench of an ordinary court of law. ${ }^{102}$

Some foreigners have questioned whether China considers the International Center for Settlement of Investment Disputes a suitable organ for settling such disputes. This center is responsible for hearing major cases concerning the investments of the World Bank. Moreover, one of the parties involved must be a governmental institution. Thus, the disputes arising from a joint venture in China are applicable. ${ }^{103}$

100. See Answers, supra note 6, at 9, 16. See also Sino-Foreign Economic Contract Law, infra note 146.1 , art. $37, \S 2 \&$ art. 38 .

101. Id. Under the Provisional Regulations on Lawyers, lawyers in the PRC are the state's legal workers; they must be citizens of the PRC and have the right to vote and be elected for office. Therefore, a lawyer of non-Chinese nationality may be invited by a foreign party to appear in the Chinese court with the status of his client's proxy rather than the status of an eligible lawyer. See Provisional Regulations on Lawyers of the PRC, Renmin Ribao, Aug. 26, 1980, arts. 1, 8, reprinted in 1 Commercial Laws and Business Regulations of the People's Republic of China 1949-1983 at 457-59 (V.F.S. Sit ed. 1983) (adopted at the 15th Session of the Standing Committee of the Fifth National People's Congress on Aug. 26, 1980) [hereinafter cited as Regulations on Lawyers].

In accordance with the same legislative spirit, the Civil Procedure Law of the PRC provides that if a foreigner or a foreign enterprise entrusts his case to a lawyer, that lawyer must be licensed in the PRC. CPL, infra note 196.

102. See Answers, supra note 6 at $9,16$.

103. Id. According to the Convention on the Settlement of Investment Disputes Between States and Nationals of Other States, Mar. 18, 1965, art. 1, § 2, 17 U.S.T. 1270, T.I.A.S. No. 6090,575 U.N.T.S. 159: "The purpose of the Center shall be to provide 
Does China agree, then, to settle investment disputes according to the arbitration regulations of the United Nations Commission on International Trade Law? Does China accept the U.N. Convention on the Recognition and Enforcement of Foreign Arbitral Awards? If parties to a dispute over the implementation of the joint venture agreement, contract or articles of association agree, the arbitration regulations of the United Nations Commission on International Trade Law may be followed, with two arbitrators appointed by each party and a notary appointed jointly by the two arbitrators. China is not a party to the United Nations Convention on the Recognition and Enforcement of Foreign Arbitral Awards. Nevertheless, if the ruling of a foreign arbitration institution does not violate China's public order, the Chinese party involved will be required to abide by the ruling. ${ }^{104}$

In the second type of dispute, between employer and employee, article 14 of the Regulation on Joint Venture Management stipulates that an attempt should be made first to solve the labor dispute through consultation between the parties. If consultation fails, either party or both parties may request arbitration by the labor management department of the people's government of the province, autonomous region or municipality where the joint venture is located. If either party disagrees with the arbitration, it may file suit with the people's court. ${ }^{105}$ As to dismissal and punishment of workers and staff by the joint venture, the trade union has the right to raise an objection if it considers such action unreasonable, and the union may send representatives to seek a solution through consultation with the board of directors. If consultation fails the matter will be handled in accordance with the procedures set forth in article 14 of the aforesaid regulations. ${ }^{106}$

In the third type of dispute, between the joint venture and other entities, if the latter is an enterprise, a corporation or a non-governmental organization, the dispute should be considered a common civil case to be settled by consultation, conciliation or arbitration, or, ultimately by a court in accordance with civil legal principles and China's civil procedure law. Article 15 of the Joint Venture Tax Law provides that in case of a dispute with the tax authorities over tax payment, a joint venture must first pay the tax as prescribed before applying to higher tax authorities for reconsideration. When a joint venture applies for reconsideration of the case in accordance with the provisions of ar-

facilities for conciliation and arbitration of investment disputes between Contracting States and nationals of other Contracting States in accordance with the provisions of this Convention." Id.

104. See Answers, supra note 6, at 9, 15.

105. Id. art. 6.

106. Provisions for JV Labor Management, supra note 48, art. 14. 
ticle 15 of the Tax Law, the tax authorities concerned are required to decide the case within three months after receiving the application. ${ }^{107}$ If the joint venture does not accept the decision after reconsideration, it may bring a suit in the local people's courts. ${ }^{108}$

It is apparent that the right of a foreign party and joint venture to use various administrative and judicial procedures to obtain remedial measures, including the right to bring a suit against specific individuals or entities, is fully protected by law. This holds true even in cases in which a government agency of the PRC is a party.

\section{B. Law of Special Economic Zones}

\section{Preferential Treatment}

In order to develop economic cooperation, technological exchange and trade, the PRC has allocated certain areas in the cities of Shenzhen, Zuhai and Shantou in Guangdong Province and Xiamen (Amoy) in Fujian Province as special economic zones (SEZ). In these areas, overseas Chinese from Hong Kong and Macao and other foreign businessmen are encouraged to set up businesses entirely on their own, or to establish joint ventures with Chinese enterprises. They are accorded preferential treatment and various conveniences and are protected under Chinese law. Special economic zones may be distinguished from other areas in China in two ways: (1) enterprises or corporations located in a SEZ can be $100 \%$ foreign owned; and (2) tax treatment and site usage provisions are highly preferential.

Both points are embodied in the Regulations of the PRC Governing Special Economic Zones in Guangdong Province. ${ }^{109}$ These regulations also apply to the Xiamen SEZ in Fujian Province.

In addition, the Guangdong People's Congress has adopted four new regulations concerning SEZs in Guangdong Province. ${ }^{110}$ Some of

107. JV Tax Law Implementation Rules, supra note 32, art. 31.

108. JV Tax Law, supra note 61 , art. 15.

109. Regulations of the PRC Governing Special Economic Zones in Guangdong Province, Renmin Ribao, Aug. 27, 1980 (approved at the 15th Session of the Standing Committee of the Fifth National People's Congress on Aug. 26, 1980) [hereinafter cited as Guangdong SEZ Regulations].

110. The four regulations are the Guangdong Provisional Entry/Exit Regulations in SEZ [hereinafter cited as GP SEZ Entry/Exit Regulations]; Guangdong Provisional Labor and Wage Regulations in SEZ [hereinafter cited as GP Labor Regulations]; Guangdong Provisional Land Regulations for Shenzhen SEZ [hereinafter cited as GP Shenzhen SEZ Land Regulations] and Guangdong Provisional Regulations for Business Registration in SEZ (adopted by the Guangdong Provincial People's Congress on Nov. 17, 1981), reprinted in Moser, Guangdong's SEZ-Four New Regulations Fill Important Gaps, China Bus. Rev., Mar.-Apr. 1982, at 41-46. 
these regulations have appeared in a recently published book, Guide to Investment in China, sponsored by the Ministry of FERT. For the Xiamen SEZ in Fujian Province, some similar local regulations were promulgated on February 24, 1985. ${ }^{111}$

The size and business scope of each SEZ is different:

(a) The Shenzhen Special Zone is bounded in the south by both Hong Kong and Kowloon. It has an area of 327 square kilometers (including the one square kilometer Shekou Industrial District under the general management of the China Merchants' Steam Navigation Company, Ltd.). In this special zone, industry, agriculture, livestock breeding, fishery, side-lines, commerce, housing and tourism projects are encouraged.

(b) The Zhuhai Special Zone borders on Macao and Gongbei, with an area of 6.8 square kilometers; the following are encouraged therein: industry, agriculture, livestock breeding, fishery, commerce, housing and tourism.

(c) The Shantou Special Zone comprises an area of 3.3 square kilometers near Longhu, in the eastern suburb of Shantou, in the southern littoral of Guangdong Province. The first stage of construction involves an area of less than one square kilometer, which is assigned for export-oriented processing industries.

(d) The Huli Special Zone of Xiamen consists of an area approximately 2.5 square kilometers in size and is situated seven kilometers to the north of Xiamen. This area is also assigned for export-oriented processing industries. Factories, enterprises and joint ventures located within the city of Xiamen and which specialize in the production of export goods also enjoy preferential treatment.

The enterprise income tax in the special zones is $15 \%$, i.e., onehalf of the joint venture income tax in other areas of China. ${ }^{12}$ The individual income tax in the special zones is levied on income above 800 yuan (renminbi) and at progressive rates ranging from 3 to $30 \%$, approximately two-thirds of the rate in the other areas of China. ${ }^{113}$ Furthermore, dividends and bonuses received from the joint ventures or enterprises within the SEZ are exempted from taxation. ${ }^{14}$

There also exists preferential treatment regarding taxation reduc-

111. See Xiamen Daily, Feb. 24, 1985, at 2.

112. Guangdong SEZ Regulations, supra note 109, art. 14.

113. The individual income tax in other areas of China rather than in the SEZ is levied on the income above RMB 800 yuan at the progressive rates ranging from $5 \%$ to $45 \%$. See Individual Income Tax Law, supra note 72, art. 3.

114. Rules of Individual Income Tax Law, supra note 72, art. 5. See also Ministry of FERT, Guide to Investment in China 133 (1982) [hereinafter cited as Guide to INVESTMENT]. 
tion and exemption:

(1) Enterprises established in 1983 and thereafter that are engaged in production for a duration of more than five years are exempted from taxation for two years; those operating in tourist and service trades are exempted from taxation for one year; and those operating in transport and communication are taxed for one year at one-half the normal rate.

(2) Enterprises in which the actual investment of foreign investors is more than U.S. $\$ 5$ million, if they involve high technology, a long capital turnover cycle and a duration of ten or more years, are exempted from taxation for five years; those operating in tourist and service trades are exempted for three years; and those operating in transport and communications are exempted for two years. ${ }^{116}$

(3) Losses in enterprises in the special zones may be set off against profits of subsequent years up to the fifth year. ${ }^{116}$

(4) Means of production and consumer goods imported with the approval of the SEZ committee for use in the special zones are exempted from import duties, with the exception of a few articles like cigarettes, liquor and wine on which an import duty is levied at onehalf of the minimum rates. For duty-free imported goods, customs only charges a service commission of $0.1 \%$ on the basis of c.i.f. prices. ${ }^{117}$

(5) Investors who reinvest their profits in the special zones for five or more years may apply for exemption of income tax on profits from such reinvestment. ${ }^{118}$

It was first announced on March 19, 1984, that some cities along the Chinese coastline from Dalian in Liaoning Province in the north to Beihai in Guangxi Zhuang Autonomous Region in the south would be selected for a special program similar to that of the SEZ, and that the Xiamen SEZ would be expanded from an area of roughly two square kilometers to the whole city of Xiamen. ${ }^{18}$ Then, on November 15, 1984, the State Council of the PRC issued Provisional Regulations on Reduction of or Exemption from Enterprise Income Tax and Unified Industrial and Commercial Tax in Special Economic Zones and Four-

115. Guangdong SEZ Regulations, supra note 109, art. 14. See also GuIDE To INVESTMENT, supra note 114 , at 134 .

116. JV Tax Law, supra note 61, art. 7. See also GuIDE To Investment, supra note 114 , at 134.

117. Guangdong SEZ Regulations, supra note 109, art. 13. See also GuIDE To INVESTMENT, supra note 114 .

118. Id. art. 16.

119. Hu Yaobang, China Would Continue Its Policy to Open to the Outside World, Renmin Ribao, Mar. 19, 1984, at 1. 
teen Coastal Port Cities. ${ }^{120}$ The regulations adjusted certain tax rates, expanded their applicable scope and provided preferential tax rates for different kinds of foreign investment.

The "Fourteen Coastal Port Cities" listed in the regulation are Dalian, Qinhuangdao, Tianjin, Yantai, Qingdao, Lianyungang, Nantong, Shanghai, Ningbuo, Wenzhou, Fuzhou, Guangzhou, Zhanjiang and Beihai.

\section{Labor and Wages in SEZs}

Labor bureaus and labor service companies have been established in the special zones. Enterprises in need of workers and office personnel may, with the permission of the appropriate labor bureau, recruit workers and office personnel directly or by recommendation of a labor service company. Recruitment is subject to satisfactory aptitude test results. In appropriate cases trial periods may be specified. ${ }^{121}$

All employment of Chinese workers and office personnel in the special zones requires an employment contract. ${ }^{122}$ Chinese workers employed in the special zones must be more than seventeen years of age; child labor is prohibited. ${ }^{123}$

The wages paid by enterprises in the special zones may take the form of payment by the piece, the hour, the day or the month. The lowest salary allowable by the wage scale is 180 yuan per month. Fifty percent of this salary is the basic wage, $20 \%$ is the floating wage, $5 \%$ is for medical care and recreation expenses and $25 \%$ is for payment to the SEZ committee or government as social welfare funds. ${ }^{124}$ Depending on the business development of an enterprise, as well as the work attitude and level of skill of the workers concerned, an increase of 5 to $15 \%$ in wages is permitted every year. ${ }^{125}$ Enterprises in the special zones should adopt an eight-hour-day and six-day work week system. Workers receive overtime pay for all overtime work. ${ }^{26}$ Workers and staff members in the special zones are entitled to time off on all national holidays. They are also entitled to legal leave (e.g., maternity leave) and seven paid vacation days each year. ${ }^{27}$

120. Zhongguo Fazhi Bao, Dec. 28, 1984, at 2.

121. GP Labor Regulations, supra note 110, arts. 3-4.

122. Id. art. 2.

123. Guide to Investment, supra note 114, at 134. See also GP Labor Regulations, supra note 110 , art. 5 . Article 5 provides: "The staff and workers employed by special zone enterprises shall be 16 years of age or older." Id.

124. GP Labor Regulations, supra note 110, arts. 8-9.

125. Id. art. 7.

126. Id. art. 10.

127. Id. art. 11. 
In order to ensure safety in production, the special zones must implement the relevant rules and regulations of the Chinese Government on labor protection. Cases of work-related injuries, disability and death are addressed by the enterprises concerned in accordance with the labor insurance regulations of the state. ${ }^{128}$

In the case of workers who, through violation of rules or regulations of the enterprise, have caused undesirable results, the enterprises concerned may take disciplinary action against them commensurate with the degree of seriousness of the offense, in the form of criticism, warnings, demerits, suspension of bonus payments, compensation for damages, demotion, or even dismissal. All cases of dismissal must be reported to the SEZ municipal labor bureau. ${ }^{129}$

\section{Land Use in SEZs}

According to the Shenzhen SEZ Land Regulations, any units and individuals wishing to use land should apply to the SEZ government. Land use is forbidden without approval and the completion of the necessary procedures. All contracts concluded directly with units and individuals currently using the land without official approval are invalid. ${ }^{130}$ Authorized units and individuals have the right to use the land, but have no ownership rights. Land sales and any disguised forms of land sales are forbidden. Leasing and unauthorized transfer of land are likewise forbidden. ${ }^{131}$ The duration of land use and its charges, however, are attractive because they are long-term and inexpensive. The maximum duration that land is permitted to be used is twenty to fifty years, according to the size and actual needs of the investment. Moreover, the use of land may be renewed upon expiration of the original term. ${ }^{132}$ The rates charged for land use vary according to the location and the purposes for which the land is used.13s

\section{Administrative Systems of SEZs}

Not only in terms of economics, but also in regard to administration, SEZs offer great convenience.

There are three SEZs in Guangdong Province-Shenzhen, Zhuhai and Shantou. The Shenzhen Special Zone includes the industrial district of Shekou, where China Merchants' Steam Navigation Company,

128. Id. arts. 12-14.

129. Id. art. 17.

130. GP Shenzhen SEZ Land Regulations, supra note 110, art. 4, at 44.

131. Id. art. 5.

132. Id. art. 15, at 45 .

133. Id. art. 16. 
Ltd. has established its construction headquarters for the Shekou industrial district. This SEZ is under the joint leadership of the Ministry of Communication of the PRC and the People's Government of the Shenzhen SEZ. In administration, the Shenzhen SEZ is under the direct leadership of the Guangdong Provincial People's Government, while the other two special zones are under the Municipal People's Government of Zhuhai and Shantou. In business matters, these special zones are under the direct management and coordination of Guangdong Provincial Administrative Committee for the SEZ.

There is one SEZ in Fujian Province, the Xiamen SEZ. The Fujian Provincial People's Government assumes administrative responsibilities for this special zone and exercises its administration through the Xiamen Municipal People's Government.

It was reported that recently a small "SEZ Office" of eight experts had been established directly under Prime Minister Zhao Ziyang and under the daily charge of State Councilor Gu Mu to enhance the direction of SEZs' principal affairs and to simplify the procedures of examination and approval. ${ }^{134}$ It seems clear that the Chinese leadership is committed at the highest levels to overseeing China's first experiment in absorbing foreign investment in special forms.

\section{Economic Contract Law}

The Economic Contract Law of the PRC was promulgated in midDecember 1981. Although its articles cannot be totally and directly applied to economic contracts relating to business with foreign nationals, it provides: "Regulations on economic and trade contracts involving foreigners shall be formulated separately with reference to the principles of this Law and international practices."13s Some important principles of the law are, therefore, worthy of note.

"Economic contracts are agreements between legal persons for the purpose of realizing certain economic goals and clarifying mutual rights and obligations." ${ }^{\text {se }}$ All the lawful rights and interests of parties to economic contracts shall be protected by this law. ${ }^{137}$ When an economic contract is formed according to the law, it has legally binding effect, and the parties must fully perform the obligations stipulated in the

134. Wenhui Bao (Hong Kong), June 26, 1982, at 1 (Am. ed.).

135. The Economic Contract Law of the PRC, art. 55, Renmin Ribao, Dec. 17, 1981 (adopted at the Fourth Session of the Fifth National People's Congress on Dec. 13, 1981) [hereinafter cited as Economic Contract Law]. For an English translation of the entire Economic Contract Law, see II:1 China Law Reporter 61 (1982), reprinted in 22 I.L.M. 330 (1983).

136. See Economic Contract Law, supra note 135, at art. 2.

137. Id. art. 1. 
contract. No party may, without prior authorization, modify or rescind the contract. ${ }^{138}$

If, due to the fault of one party, an economic contract cannot be performed, the party at fault shall be liable for breach of the contract; if both parties are at fault, each party shall be liable for the breach of contract commensurate with its responsibility.

If an individual is directly responsible for dereliction of duty, malfeasance or other unlawful conduct that gives rise to a major accident or severe loss, he shall be investigated for economic and administrative liability, as well as criminal liability. ${ }^{130}$

If, due to the fault of higher-level authorities or authorities in charge of operations, an economic contract cannot be performed, the higher-level authorities or authorities in charge of operations shall be liable for breach of contract. The breaching party shall, as provided, first pay the other party breach of contract or compensatory damages, and then the liability of the responsible higher-level authorities or authorities in charge of operations shall be determined. ${ }^{140}$

If a party breaches an economic contract, it shall pay breach of contract damages to the other party. If the breach of contract has already caused the other party to suffer losses that exceed the amount of the breach of contract damages, the breaching party shall pay compensation and supplement the breach of contract damages by the insufficient amount. If the other party demands continued performance of the contract, the breaching party shall continue to perform. ${ }^{141}$

Breach of contract and compensatory damages shall be paid within ten days after liability is clearly established, otherwise the matter will be handled as an overdue payment. ${ }^{142}$

If disputes over an economic contract develop, the parties shall resolve them through consultation. If consultation is not successful, any party may apply to the contract administration authorities specified by the state for mediation or arbitration. The party may also bring a lawsuit in the people's court. ${ }^{143}$

If mediation results in an agreement, the parties shall abide by the terms of the agreement. In the case of a decision made after arbitration, the contract administration authorities specified by the state shall issue a written arbitration decision. If one party or both parties do not agree with the arbitration, they may, within fifteen days after receipt

138. Id. art. 6.

139. Id. art. 32 .

140. Id. art. 33 .

141. Id. art. 35 .

142. Id. art. 37.

143. Id. art. 48. 
of the written arbitration decision, bring a lawsuit in the people's court; if no suit is filed within that period, the arbitration decision shall have legal effect. ${ }^{144}$

If the parties to an economic contract have not voluntarily performed within the time period prescribed within the mediation agreement, written arbitration decision or court judgment, the People's Bank, the specialized banks and the credit co-operatives, upon receipt of a notice from the people's court requesting assistance in carrying out the relevant awards, shall debit or transfer credits from the party's account in the amount required to make payment. The provisions of this law apply to all contracts for purchase and sale, construction work, processing, transportation of goods, supply and use of electricity, storage and safekeeping, the lease of property, loans, property insurance, scientific and technical cooperation, and other economic contracts. ${ }^{145}$

\section{Sino-Foreign Economic Contract Law}

Four years after the promulgation of the Economic Contract Law of the PRC, the Sino-Foreign Economic Contract Law was approved on March 21, 1985. ${ }^{146}$ The contract law, aimed at promoting China's foreign economic relations and protecting the legitimate rights and interests of both foreign and Chinese contractors, became effective on July $1,1985 .{ }^{147}$

The law applies to economic contracts between Chinese enterprises or other economic institutions and their foreign counterparts or individuals, excluding international transport contracts. ${ }^{148}$ The law stipulates that the parties involved may settle disputes in accordance with laws they choose, provided that the laws apply to such disputes. If the parties make no choice, the law of the country most closely related to the contract will apply. ${ }^{149}$ Contracts for joint ventures, cooperative management and prospecting, and development of natural resources in China, however, are subject to Chinese law only. ${ }^{150}$

These contracts will remain effective regardless of future changes in related Chinese laws. ${ }^{151}$ In case there are no relevant stipulations in

144. Id. art. 49 .

145. Id. art. $52, \S 3 \&$ art. 8.

146. Sino-Foreign Economic Contract Law of the PRC, Renmin Ribao, Mar. 22, 1985, at 2 .

147. Id. arts. $1,43$.

148. Id. art. 2.

149. Id. art $5, \S 1$.

150. Id. \& 2

151. Id. art 40. 
Chinese laws, international norms will apply. ${ }^{162}$ If the relevant Chinese laws conflict with international treaties to which China is a signatory, the international treaty stipulations will apply, with the exception of articles to which China has declared reservations. ${ }^{103}$

The law also stipulates that in case the parties do not want to settle their disputes through reconciliation, or if reconciliation fails, the parties may submit the case to Chinese or other arbitration bodies according to the related contract provisions. ${ }^{154}$ They may also bring it to a Chinese court if no arbitration clause is included in the contract and the parties fail to reach a written agreement on arbitration. ${ }^{165}$

\section{E. Trademark Law}

The Trademark Law of the PRC was adopted on August 23, 1982 and entered into force on March 1, 1983. The former "Regulations Governing Trademarks" promulgated by the State Council in 1963 were contemporaneously abrogated. ${ }^{156}$ Compared to the former regulations, the new Trademark Law contains a number of new provisions. The Trademark Law protects the proprietorship of registered trademarks and gives prominence to explicit provisions protecting the rights and interests of registered trademark owners. A spokesman for the China group of the International Association for the Protection of Industrial Property Rights remarked that China's new Trademark Law will play an important role in stimulating the country's commodity economy, perfecting the legislation concerning China's industrial property rights and promoting its foreign trade. ${ }^{167}$

Any foreigner or foreign enterprise intending to apply for the registration of a trademark in China must file an application in accordance with any agreement between the PRC and the country to which the applicant belongs, ${ }^{168}$ according to the international treaty to which

152. Id. art. 5, § 3 .

153. Id. art. 6.

154. Id. art. $37, \S 2$.

155. Id. art. 38.

156. Trademark Law of the PRC, Renmin Ribao, Aug. 27, 1983, reprinted in 1 Сoмmercial Laws and Business Regulations of the People's Republic of China 1949-1983 at 289-93 (V.F.S. Sit ed. 1983) (adopted at the 24th Session of the Standing Committee of the Fifth National People's Congress on Aug. 23, 1982) [hereinafter cited as Trademark Law].

157. China Group Spokesman on New Chinese Trademark Law, China Economic News, No. 46, Nov. 29, 1982, at 1.

158. People's Republic of China Trade Relations, July 7, 1979, United States-P.R.C., art. $6, \S 2,31$ U.S.T. $4651,4657-5 B$, T.I.A.S. No. 9630 [hereinafter cited as Sino-American Trade Agreement]. The Sino-American Agreement on Trade stipulates: "Both Contracting Parties agree that on the basis of reciprocity legal or natural persons of either 
both countries are parties, or on the basis of the principle of reciprocity. ${ }^{158}$

Any foreigner or foreign enterprise intending to apply for the registration of a trademark, or to deal with other matters concerning a trademark in China, shall entrust the organization designated by the state to act on his or its behalf. ${ }^{160}$

The Trademark Office of the Administrative Authority of Industry and Commerce under the State Council shall be responsible for the registration and administrative control of trademarks throughout the country. A registered trademark means one which has been approved and registered by the Trademark Office. The trademark registrant shall enjoy an exclusive right to use the trademark. ${ }^{161}$

The Trademark Review and Adjudication Board, established under the Administrative Authority for Industry and Commerce under the State Council, shall be responsible for handling trademark disputes. ${ }^{162}$

According to articles 23 and 24, the term of validity for a registered trademark shall be ten years from the date of approval. An application for renewal may be filed six months before the expiration date. The period of validity for a renewal is also ten years. This is a revision of the past practice in which the validity for registered foreign trademarks was limited to ten years while domestic trademarks had no time limit.

Provisions on trademark licensing have been added. Article 26 provides that the owner of a registered trademark may give permission to another person to use his trademark on the register by signing a trademark license contract and submitting it to the Trademark Office for recordation. Furthermore, new provisions have been added to encourage licensing, since trademark licensing is now receiving greater attention from domestic and foreign enterprises.

In order to effectively protect the exclusive right to use registered trademarks, the Trademark Law created a special chapter which clearly defines infringements on such rights and specifies penalties for such infringements. It provides that the exclusive right to use a registered trademark is limited to the approved trademark and to the spe-

Party may apply for registration of trademarks and acquire exclusive rights thereto in the territory of the other Party in accordance with its laws and regulations."

159. See Trademark Law, supra note 156, art. 9.

160. Id. art. 10. The so-called "organization designated by the State" refers to the China Council for the Promotion of International Trade (CCPIT). The CCPIT has a Trademark Agency for handling such matters.

161. Id. arts. 2-3.

162. Id. art. 20. 
cific goods relating to the approved trademark. ${ }^{163}$

Any of the following acts shall be deemed an infringement of the exclusive right to use a registered trademark: (1) to use a trademark which is identical or similar to the registered trademark in respect to the same or similar goods without the authorization of the proprietor of the registered trademark, (2) to make or sell, without authorization, representations of the registered trademark of another person or (3) to cause in other respects prejudice to the exclusive right to use the registered trademark of another person. ${ }^{164}$

In the event of any infringement on the exclusive right to use a registered trademark as provided for in article 38 , the party whose right was infringed may request the administrative authorities for industry and commerce of the location (domicile or establishment) of the infringer to handle the matter. The administrative authority for industry and commerce concerned has the power to order the infringer to stop the infringing act immediately and to compensate the party whose right was infringed for the damages suffered. The amount of compensation shall be the profit which the infringer has earned through the infringement during the period of the infringement or the damages that the party whose right was infringed has suffered during that period. If the circumstances are serious, the authority may, in addition, impose a fine. Any dissatisfied party may institute proceedings in the people's court within fifteen days from the receipt of the notice. If no proceedings are instituted or if there is no performance (complying with the decision imposing the fine) by the expiration of the specified period, the administrative authority for industry and commerce concerned may request compulsory execution from the people's court.

Where the exclusive right to use the registered trademark was infringed, the party whose right was infringed may institute proceedings directly with the people's court. ${ }^{185}$

Any party that passes off a trademark as a registered trademark of another person-including any party that makes or sells, without authorization, representations of the registered trademark of another person-shall compensate the party whose right was infringed for the damages suffered and shall receive a fine. Furthermore, any person directly responsible for the passing off shall be prosecuted, according to law, for any criminal responsibilities. ${ }^{188}$

One of the differences between the Trademark Law of the PRC

163. Id. art. 37.

164. Id. art. 38.

165. Id. art. 39.

166. Id. art. 40. 
and those of capitalist countries is that China's trademark registration will help supervise merchandise quality and protect consumer interests. Articles 1 and 6 state that the owner of a registered trademark should be responsible for the quality of goods as advertised by the attached trademark, and departments in charge of the administration of industry and commerce should supervise merchandise quality and prevent cheating through trademark registration.

Articles 31 and 34 provide that in cases where goods to which a registered trademark is attached are manufactured in a slipshod manner or goods of inferior quality are offered for sale, departments of administration of industry and commerce shall order corrections to be made within a prescribed time limit, circulate a notice of criticism, impose a fine or have the trademarks revoked by the Trademark Office. Trademark laws of capitalist countries, on the other hand, are designed to protect only the proprietorship of a registered trademark from infringement. Those laws contain no provisions protecting consumer interests. This point highlights the uniqueness of socialist China's trademark law. ${ }^{187}$

\section{F. Patent Law}

The Patent Law of the PRC, which includes sixty-nine articles in eight chapters, was adopted on March 12, 1984 and entered into force on April 1, 1985. ${ }^{188}$ It effectively protects the legal rights and interests of patentees, and seeks to further mobilize the enthusiasm of units and individuals to make inventions. At the same time the law helps dispel foreigners' worries about exporting technology to China. ${ }^{168}$

The law was enacted to protect patent rights for "inventions-creations," including inventions, utility models and designs. ${ }^{170}$ The Patent Office of the PRC receives and examines patent applications and grants patent rights for inventions-creations that conform with the provisions of the law. ${ }^{171}$

Inventions-creations are divided into two categories: service and non-service. The former refers to an invention-creation made by a person in execution of tasks of the entity to which he belongs or made by that person individually while using the material means of the entity;

167. See China Group Spokesman, supra note 157, at 2.

168. Patent Law of the PRC, Renmin Ribao, Mar. 15, 1985, at 2 (adopted at the Fourth Session of the Standing Committee of the Sixth National People's Congress) [hereinafter cited as Patent Law].

169. A Good Beginning for the Establishment of China's Patent Law, Renmin Ribao, Mar. 15, 1984, at 1 (Editorial).

170. Patent Law, supra note 168, arts. 1-2.

171. Id. art. 3. 
the latter refers to an invention-creation made in a different manner. For a service invention-creation made by any staff member or worker of a foreign enterprise, or of a Chinese-foreign joint venture located in China, the right to apply for a patent belongs to the enterprise. For any non-service invention-creation, the right to apply for a patent belongs to the inventor or creator. After the application is approved, the patent right is owned by either the enterprise or the individual. ${ }^{172}$

The right to apply for a patent or the patent right may be assigned. To assign this right the parties must conclude a written contract, which becomes effective after it is registered with the Patent Office and an announcement is made. ${ }^{173}$

After the grant of the patent right for an invention, utility model or design, no entity or individual may, without the authorization of the patentee, exploit the patent, make, use or sell the patented product, or use the patented process for production or business purposes. ${ }^{174} \mathrm{Al}$ though there are a few exceptions provided in article 14 of the Patent Law, it only applies to Chinese state-run entities, collective entities or Chinese individuals, i.e., not to foreign enterprises or Sino-foreign joint ventures located in China, nor to foreign individuals. ${ }^{175}$

Any entity or individual exploiting the patent of another must conclude with the patentee a written license contract for exploitation and pay the patentee a fee. The licensee has no right to authorize any additional entity or individual to exploit the patent. ${ }^{178}$

If a foreigner, foreign enterprise or other foreign organization that has no habitual residence or business office in China files an application for a patent in China, the application will be treated under the Patent Law in accordance with any agreement concluded between the country to which the applicant belongs and China, or in accordance with any international treaty to which both countries are parties, or on the basis of the principle of reciprocity. ${ }^{177}$ If a foreign individual or entity applies for a patent, or has other patent matters to attend to in China, he or it shall appoint a patent agent designated by the State Council of the PRC to act as his or its agent. ${ }^{178}$

After several years of effort, China has formed a patent service network with a central national patent office. The Beijing-based $\mathrm{Na}$ -

172. Id. art. $6, \S 2$.

173. Id. art. $10, \S \S 1,4$.

174. Id. art. $11, \S \S 1-2$.

175. Id. art. 14, \$§ 1-2. See also Zhang You-yu, Writing While the Patent Law is

Being Promulgated. Zhongguo Fazhi Bao, Mar. 19, 1984, at 2.

176. Patent Law, supra note 168, art. 12.

177. Id. art. 18.

178. Id. art. $19, \S 1$. 
tional Patent Office was established in 1980 with a branch office in Shanghai. There are agencies in Liaoning, Shandong, Hunan and other provinces. Patent affairs in other areas of the country are handled by local science and technology commissions. The National Patent Office acts as the recipient of all patent applications and the official patentor. The Office has five patent appraisal sections staffed with about 200 engineers. It also has sections in charge of patent transfers and legislation. The patent document center set up by the Office now has a collection of some twenty million foreign patent documents, the largest in China. ${ }^{178}$

Bulletins and documents issued by the Office are printed by a patent document publishing house. China now has two journals on patents, Patents of China and World Inventions. These monthly publications are also printed by the publishing house. Moreover, there is a patent document advisory station in Shijiazhuang, the capital of Hebei Province. It offers services concerning patents, including the translation of documents from Japanese, English, German and Russian into Chinese. Similar stations will appear in other parts of the country. According to the Chinese Patent Office, about 11,500 staff have been trained in short-term courses given at central and local levels since 1979. ${ }^{180}$

Any invention or utility model for which patent rights may be granted must possess novelty, inventiveness and practical applicability. ${ }^{181}$ Any design for which patent rights may be granted must not be identical or similar to any design which, before the date of filing, has been publicly disclosed in any publication in China or abroad or has been publicly used in China. ${ }^{182}$

If, after a substantive examination, there is no cause for rejection of the patent application for an invention, the Patent Office will make a decision, announce it and notify the applicant. ${ }^{18 s}$ If, after receiving the application for a patent for a utility, model or design, the Patent Office finds upon preliminary examination that the application is not in conformity with the requirements of the law, it shall not proceed to examine it as to substance but shall immediately make an announcement and notify the applicant. ${ }^{184}$

If no opposition to the application for a patent is filed or, after

179. See China Forms Patent Service Network, Zinhau News Agency Bulletin, Mar. 15,1984 , at $17-18$.

180. Id.

181. Patent Law, supra note 168 , art. $22, \S 1$.

182. Id. art. 23.

183. Id. art. 39.

184. Id. art. 40. 
examination, the opposition is deemed unjustified, the Patent Office shall make a decision to grant the patent right, issue the patent certificate, and register and announce relevant matters. ${ }^{185}$

The duration of patent rights for inventions is fifteen years from the date of filing. The duration of patent rights for utility models or designs is five years from the date of filing, subject, before the expiration of the said term, to a three year renewal. ${ }^{186}$

Under the law, the patentee has the obligation to make the patented product or use the patented process in China, or to authorize other persons to make the patented product or use the patented process in China. ${ }^{187}$ Where the patentee of an invention or utility model fails, without any justified reason, by the expiration of three years from the date of the grant of the patent right to fulfill the obligation aforesaid, the Patent Office may, upon the request of an entity which is qualified to exploit the invention or utility model, grant a compulsory license to exploit the patent. ${ }^{188}$ The entity or individual that is granted a compulsory license for exploitation, however, must pay to the patentee a reasonable exploitation fee, the amount of which shall be fixed by both parties in consultations. If the parties fail to reach an agreement, the Patent Office will adjudicate the dispute. ${ }^{189}$ In case the patentee is not satisfied with the decision of the Patent Office granting a compulsory license for exploitation or adjudicating the fee payable for exploitation, the patentee may, within three months of the receipt of the notification, institute legal proceedings in the people's court. ${ }^{180}$

In response to any unauthorized exploitation of the patent constituting an infringing act, the patentee or any interested party may request the administrative authority for patent affairs to intervene or may directly institute legal proceedings in the people's court. The administrative authority for patent affairs handling the matter has the power to order the infringer to stop the infringing act and to pay the patentee or interested party damages. Any dissatisfied party may: within three months from the receipt of the notification, institute legal proceedings in the people's court. If such proceedings are not instituted within the time limit and if the order is not complied with, the administrative authority for patent affairs may approach the people's court for compulsory execution. ${ }^{191}$

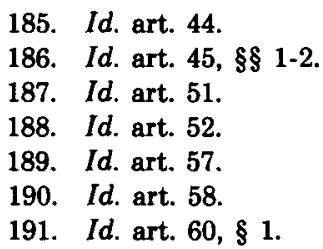


If any person passes off the patent of another person, such passing off shall be treated as an infringing act. In case the circumstances are serious, any person directly responsible shall be prosecuted for his criminal liability. ${ }^{192}$

Until the publication or announcement of the publication of a patent, staff members of the Patent Office and persons involved have a duty to keep its contents secret. ${ }^{103}$ If any staff member of the Patent Office or any staff member of the state acts wrongfully for personal gain or commits fraudulent acts, he shall be subject to disciplinary sanctions by the Patent Office or any other competent authority. If the circumstances are serious, he shall be prosecuted for his criminal liability. ${ }^{194}$

In addition to its domestic legislation, China acceded to the Paris Convention on the Protection of Industrial Property on November 14, 1984. The only reservation involves section 1 of article 28 in the Convention. ${ }^{195}$ Thus, China has formally joined the international network for the protection of patent rights as well as trademark rights.

\section{Procedure Laws}

In addition to substantive laws, China has promulgated a series of procedural laws which affect foreign investors. They are the Civil Procedure Law of the PRC and the Provisional Rules of Procedure of the Foreign Trade Arbitration Commission of the China Council for the Promotion of International Trade (CCPIT).

\section{A. Civil Procedure Law}

As a general jurisdictional principle of a sovereign state, the Civil Procedure Law provides: "All civil litigation conducted in the territory of the PRC must observe this law." "For For the purpose of protecting the right to bring an action of foreigners who live or do business in China, and also for their convenience, this law contains a special provision entitled "Special Regulations of Civil Procedure Involving Foreigners."

192. Id. art. 63.

193. Id. art. 21.

194. Id. art. 66 .

195. See Decision on Acceding to the Paris Convention on Protection of Industrial Property, Renmin Ribao, Nov. 15, 1984 (adopted at the Eighth Session of the Standing Committee of the Sixth National People's Congress on Nov. 14, 1984).

196. Civil Procedure Law of the PRC (for trial implementation), art. 3, § 1, Renmin Ribao, Mar. 14, 1982 (adopted at the 22nd Session of the Standing Committee of the Fifth National People's Congress on Mar. 8, 1982) [hereinafter cited as CPL]. 
On the basis of equality and mutual benefit, the law explicitly stipulates:

(1) A foreigner or stateless person who brings an action or responds to an action in a people's court shall have the same procedural rights and obligations as a citizen of the PRC.

(2) A foreign enterprise or organ that brings an action or responds to an action in a people's court shall enjoy and bear rights and obligations according to this law. ${ }^{187}$

(3) If a foreign forum imposes limits on the civil procedural rights of a citizen, enterprise or organization of the PRC, the people's court shall carry out the principle of reciprocity with respect to the civil procedural rights of the citizens, enterprises or organizations of that country. ${ }^{198}$

(4) In hearing cases involving foreigners, the people's court shall use the spoken and written language commonly used in the PRC. Translation may be provided if the party so requests and the fee shall be borne by that party. ${ }^{198}$

(5) If a foreigner, stateless person, foreign enterprise or organization brings an action or responds to an action in the people's court and entrusts his case to a lawyer, he must entrust it to a lawyer licensed in the PRC. ${ }^{200}$

With regard to arbitration, the law provides that disputes arising from foreign economic interests, trade, transportation or maritime incidents which the parties have submitted for arbitration, according to a written agreement between the parties, to the PRC's arbitration organ concerning foreigners, shall not be brought in a people's court. If there is no such written agreement, an action may be brought in a people's court.

In the case of disputes arising from foreign economic interests, trade, transportation and maritime incidents between foreign enterprises or organizations, the parties may, according to their written agreement, present their dispute to the PRC's arbitration organ concerning foreigners and may also bring an action in the appropriate people's court. ${ }^{201} \mathrm{~A}$ case that has been arbitrated by the PRC's arbitration organ concerning foreigners, however, shall not be brought by the parties in a people's court. ${ }^{202}$ This provision is quite different from that of

197. Id. art. 186.

198. Id. art. 187.

199. Id. art. 190.

200. Id. art. 191, § 1.

201. Id. art. 192.

202. Id. art. 193. 
the domestic economic contract. ${ }^{203}$

If one party does not pay the award granted by the PRC's arbitration organ concerning foreigners, the other party may apply to the intermediate people's court, in the place where the said arbitration organ is located, or where the property is located, for enforcement according to the relevant regulations provided by this law. ${ }^{204}$

The Special Regulations of Civil Procedure Involving Foreigners, consists of twenty-one articles. They are the fifth and last part of the Civil Procedure Law. These regulations are applicable to civil actions conducted by foreigners, stateless persons, foreign enterprises and organizations in the PRC. The other four parts consist of 184 articles and contain regulations regarding jurisdiction, organization of adjudication, withdrawal, participants (including litigants and their representatives) in proceedings, evidence, coercive measures against obstruction of civil actions, litigation fees, procedure for first instance, procedure for second instance, procedure for adjudication supervision, and procedure for enforcement. The regulations of this law are applicable to foreigners, as are all relevant regulations provided by other parts of this law if there are no specific provisions in part five. ${ }^{205}$

Although some procedures are specifically stipulated in this law, if there is inconsistency among the regulations provided by an international treaty entered into by the PRC and this law, the regulation or regulations provided by that international treaty shall be applied, with the exception of those provisions to which the PRC has announced reservations. ${ }^{208}$

In order to develop international cooperation in the area of judicial assistance, the Civil Procedure Law further stipulates that China's courts and foreign courts may entrust each other with certain procedural acts according to any treaty entered into or participated in by the PRC, or to the principle of reciprocity. Matters entrusted by a foreign court to the people's courts which contradict the sovereignty or security of the PRC shall be rejected; matters which do not belong within the jurisdiction of the people's court shall be returned to the foreign court with the reason therefore explained. ${ }^{207}$

The people's court of the PRC shall make an order recognizing the effectiveness of a final judgment or order entrusted to it for enforcement by a foreign court, and shall enforce it in accordance with the procedures stipulated by this law, after reviewing and deciding, accord-

203. See supra note 141 and accompanying text.

204. Id. art. 195.

205. Id. art. 185.

206. Id. art. 189.

207. Id. art. 202. 
ing to the international treaties entered into or participated in by the PRC, or according to the principle of reciprocity, that it does not violate any fundamental principles of the laws of the PRC or the interests of the country and society. Otherwise, the judgment or order shall be returned to the foreign court. ${ }^{208}$

\section{B. Arbitration Rules}

In China, arbitration is one of the principal methods for settling disputes arising from economic dealings and trade with foreign countries. As noted earlier, article 14 of the Joint Venture Law provides that disputes arising between parties to a joint venture which the board of directors fail to settle through consultation may be settled through conciliation or arbitration by an arbitral body of China or through arbitration by any other arbitral body agreed to by the parties. ${ }^{208}$

In the early years after the founding of the PRC, a complete arbitral system was established. On May 6, 1954, the Administration Council of the Central People's Government adopted the Decision for the Establishment of a Foreign Trade Arbitration Commission within the China Council for the Promotion of International Trade. ${ }^{210}$ In accordance with this decision, the CCPIT issued Provisional Rules of Procedure of the Foreign Trade Arbitration Commission in March 1956. ${ }^{211}$ In recent years, in order to meet the growing needs of China's trade and economic relations with foreign states, the State Council decided in February 1980 to change the name of the Foreign Trade Arbitration Commission to the Foreign Economic and Trade Arbitration Commission (FETAC) and to enlarge its scope and structure. ${ }^{212}$ The Arbitration Commission is composed of fifteen to twenty-one members selected and appointed for one year terms by the CCPIT. The members have special knowledge and experience in foreign trade, commerce, in.

208. Id. art. 204.

209. See Joint Venture Law, supra note 13, art. 14 and text accompanying note 99.

210. Decision of the Government Administration Council of the Central People's Government Concerning the Establishment of a Foreign Trade Arbitration Commission Within the China Council for the Promotion of International Trade, art. 12 (1954), reprinted in 2 Commercial, Business and Trade Laws: Pzople's Republic of China $§$ L.2 (F. Chu, M. Moser \& Q. Nee eds. 1983) [hereinafter cited as Decision of 1954].

211. Provisional Rules of Procedure of the Foreign Trade Arbitration Commission of the China Council for the Promotion of International Trade, arts. 1-38 (1956), reprinted in id. $\S$ L.3 [hereinafter cited as FETAC Rules].

212. See Notice of the State Council Concerning the Conversion of the Foreign Trade Arbitration Commission into the Foreign Economic and Trade Arbitration Commission (1980), reprinted in id. § L.6 [hereinafter cited as Notice of 1980]. 
dustry, agriculture, transportation, insurance or law. ${ }^{213}$ A 1980 notice indicated that the number of members of FETAC may appropriately increase to accommodate an expanding workload. ${ }^{214}$

FETAC has been authorized to handle disputes arising from the execution of agreements for joint ventures involving foreign interests, foreign investment in China, credits and loans between China and foreign banks, production between Chinese and foreign parties, and compensation and other matters relating to trade with foreign countries. ${ }^{215}$ In handling a case, FETAC adheres to the policy of equality and mutual benefit and pays due regard to international practice. FETAC strictly abides by Chinese law and observes the terms of any contract concerned in the dispute.

In practice, FETAC combines arbitration with conciliation. It seeks to settle disputes through conciliation wherever possible on the basis of voluntary agreement by both parties. Conciliation is neither compulsory nor inevitable prior to or during the arbitration proceedings. If one of the parties is unwilling, attempts at conciliation will be ignored. Conciliation is conducted on the principled basis of discerning between right and wrong and ascertaining the liabilities of each side in accordance with the laws of China. A conciliatory statement is made at the close of a case in accordance with any conciliatory agreement. FETAC's experience has proved that most disputes can be settled by conciliation, and the procedure is appreciated by a number of Chinese and foreign parties.

In the past few years, FETAC has developed joint conciliations in collaboration with foreign arbitral bodies. In cooperation with the American Arbitration Association, FETAC has succeeded in settling some disputes arising from United States-China trade with satisfactory results. In addition, the CCPIT and the Bureau of Industrial Property of France have signed a Protocol for Settlement of Disputes Arising from Franco-Chinese Industrial Property Trade. The Protocol stipulates that disputes arising from industrial property trade may be settled through joint conciliation.

In the event that no settlement can be reached through conciliation, or if one party refuses to participate in the process, FETAC will arbitrate the case pursuant to the arbitration agreement signed between the parties. Arbitration agreements must be in writing. The most common form of agreement is an arbitration clause in the basic

213. Decision of 1954 , supra note 210 , art. 3 .

214. See FETAC Rules, supra note 211, art. 13.

215. Decision of 1954, supra note 210 , art. 3. 
contract entered into by the parties. ${ }^{216}$ Once there is such an agreement, the people's court will not accept an application for litigation. ${ }^{217}$

Either party may file an application for arbitration with FETAC according to their agreement to arbitrate. In accordance with FETAC's rules of procedure on arbitration, each of the disputing parties has the right to appoint one person as an arbitrator from among the FETAC members. The two arbitrators so appointed jointly select a presiding arbitrator from among the FETAC members, and the three together form an arbitration tribunal to hear the case. ${ }^{218}$ In the alternative, the disputing parties may jointly choose one person to serve as a sole arbitrator from among the FETAC members. ${ }^{218}$

If necessary, the arbitration tribunal may consult experts to clarify any questions concerning technical or special matters or business practices. Such experts may be designated from among citizens of the PRC or foreign citizens. ${ }^{220}$

In general, the arbitration tribunal hears cases openly. The arbitration tribunal may also conduct closed hearings, however, if either or both of the disputing parties so request. ${ }^{221}$ Timely notice of hearing dates shall be given to the parties. The parties may confer with FETAC on matters relating to the proceeding either in person or through their attorney (with the status of representative rather than of lawyer), who may be a citizen of the PRC or a foreign citizen. Attorneys may attend hearings on behalf of the parties represented. ${ }^{222}$

216. See, e.g., FETAC Rules, supra note 211, art. 3 (adopted on Mar. 31, 1956 at the Fourth Committee Meeting of the China Council for the Promotion of International Trade), reprinted in Commercial Laws and Business Regulations of the People's RePUBLic of China 1949-1983 at 447-49 (V.F.S. Sit ed. 1983): "Any other form of agreement to submit to arbitration, [however,] such as special agreement, exchange of correspondence or any specific stipulation contained in other relevant documents" will be recognized. Id.

217. CPL, supra note 196, art. 192.

218. Article 4 requires that the party commencing the arbitration specify its choice of arbitrator in its application, or that it authorize the chairman of FETAC to appoint the arbitrator on behalf of the applicant. FETAC Rules, supra note 211, art. 4c. Within fifteen days of its receipt of the arbitration application, the respondent shall similarly choose its arbitrator, or authorize the FETAC chairman to so choose. Id. art. 9. The two arbitrators then "select an umpire from among the members" of FETAC. Id. art. 1.

219. Id. art. 12 .

220. Id. art. 27.

221. Id. art. 21.

222. Id. art. 18. But cf. Regulations on Lawyers, supra note 101, arts. 1, 3, 5, 8. These provisional regulations, it has been contended, "state by implication that foreign counsel is not qualified to practice law in China, and therefore cannot represent the foreign party during arbitration." P. WiK, How to do Business with the People's Republic of China 150 (1984). 
When the arbitration tribunal is composed of three arbitrators, the award is decided by a majority vote and reasons for the decision must be given in the award. ${ }^{223}$ The award granted is final, and neither party may appeal the decision to a court of law or to any other organization. The parties shall automatically execute the award within the time limit specified in the award. If one of the parties fails to execute it after the expiration of the time limit, the opposing party may petition the people's court to enforce it in accordance with law. ${ }^{224}$

To compensate for the costs of arbitration, the arbitration tribunal may collect a fee not exceeding $1 \%$ of the amount of the claim. In accordance with the arbitration award, such a fee should be borne entirely by the losing party or proportionally by both parties. ${ }^{225}$

Pursuant to the Law on Chinese-Foreign Joint Ventures, parties to a joint venture may by agreement submit to arbitration by an arbitral body other than a Chinese one. ${ }^{228}$ In such a case, the following procedures are often adopted: ${ }^{227}$

(1) Arbitration by an arbitral body of the defendant's country: If the defendant is Chinese, the arbitration is carried out by an arbitral body of China; if the defendant is a foreign party, the arbitration is held by an arbitral body of the foreign party's country.

(2) Arbitration in a third country: The dispute shall first be referred to a Chinese arbitral body for conciliation, and if conciliation fails to produce results, it is submitted for arbitration to an arbitral body in a third country.

(3) No matter where the arbitration is held, in the defendant's country or a third country, the procedural rules of the arbitral body in which the arbitration is conducted shall apply.

(4) Both parties may also agree to submit their dispute for arbitration on an ad hoc basis to an arbitral tribunal organized in accordance with the United Nations Commission on International Trade Law (UNCITRAL) Arbitration Rules. ${ }^{228}$

223. FETAC Rules, supra note 211, arts. 20, 29, 30.

224. Id. arts. 31-32.

225. Id. art. 33.

226. Joint Venture Law, supra note 13, art. 14.

227. See, Guide to Investment, supra note 114, at 232 . The basic principles mentioned in the text have been stipulated in some bilateral international agreements. See, e.g., the Sino-American Trade Agreement, supra note 158, art. 8, at 4659. This treaty omits the requirement of refering the dispute to a Chinese arbitration tribunal before submitting it to third country arbitration.

228. Id. at 4659-60. 


\section{Conclusion}

Since China began its legislation for absorbing foreign investment in 1979, many relevant laws and regulations have been promulgated. Although the relevant legal framework is still incomplete, laws both preferential and favorable to foreign investors have now been firmly established. Furthermore, China has begun to prepare another series of laws and regulations concerning, inter alia, private investment in China, foreign independent enterprises in China and Chinese-foreign cooperative enterprises; these laws will be promulgated consecutively. ${ }^{228}$ The PRC is developing a complete legal system to accelerate the absorption of foreign investment and international economic exchange.

The aforesaid policies and laws illustrate that China's door is open much wider than at any time since the People's Republic was founded in 1949. As Premier Zhao Zhiyang indicated, China's policy of opening to the outside world is not a mere subjective wish but a reflection of an objective necessity; therefore, it is China's "basic national policy" and "will long remain unchanged. China has opened its door and will never close it again. Instead, as China gradually realizes its modernization program, its external economic relations will grow steadily in depth and width." 230

229. As reported, this information was disclosed by the Vice-Minister of FERT of China, Wei Yuming. See Green Light for Establishing Foreign Enterprises in China's Coastal Areas, China Economic News (Hong Kong) No. 42, Oct. 31, 1983, at 1.

230. China's Policy of Opening to Outside to Remain Unchanged, Says Premier Zhao, Zinhau News Agency Bulletin, Jan. 12, 1984, at 74-75. 
